\title{
Effects of Land Use and Pollution Loadings on Ecotoxicological Assays and Bacterial Taxonomical Diversity in Constructed Wetlands
}

\author{
Subhomita Ghosh Roy ${ }^{1, *}$, Charles F. Wimpee ${ }^{1}$, Stephen A. McGuire ${ }^{1,2}$ and Timothy J. Ehlinger ${ }^{1,2}$ \\ 1 Department of Biological Sciences, University of Wisconsin-Milwaukee, P.O. Box 413, \\ Milwaukee, WI 53201-0413, USA; cwimpee@uwm.edu (C.F.W.); smcguire@uwm.edu (S.A.M.); \\ ehlinger@uwm.edu (T.J.E.) \\ 2 Institute for Systems Change and Peacebuilding, University of Wisconsin Milwaukee, P.O. Box 413, \\ Milwaukee, WI 53201-0413, USA \\ * Correspondence: ghoshroy@uwm.edu
}

check for updates

Citation: Ghosh Roy, S.; Wimpee, C.F.; McGuire, S.A.; Ehlinger, T.J. Effects of Land Use and Pollution Loadings on Ecotoxicological Assays and Bacterial Taxonomical Diversity in Constructed Wetlands. Diversity 2021, 13, 149. https://doi.org/ $10.3390 / \mathrm{d} 13040149$

Academic Editors: Stuart Donachie and Michael Wink

Received: 14 February 2021

Accepted: 27 March 2021

Published: 30 March 2021

Publisher's Note: MDPI stays neutral with regard to jurisdictional claims in published maps and institutional affiliations.

Copyright: (c) 2021 by the authors. Licensee MDPI, Basel, Switzerland. This article is an open access article distributed under the terms and conditions of the Creative Commons Attribution (CC BY) license (https:// creativecommons.org/licenses/by/ $4.0 /)$.

\begin{abstract}
Freshwater ecosystems are affected by anthropogenic alterations. Different studies have extensively studied the concentrations of metals, nutrients, and water quality as measurements of pollution in freshwater ecosystems. However, few studies have been able to link these pollutants to bioindicators as a risk assessment tool. This study aimed to examine the potential of two bioindicators, plant ecotoxicological assays and sediment bacterial taxonomic diversity, in ecological risk assessment for six freshwater constructed wetlands in a rapidly urbanizing watershed with diverse land uses. Sediment samples were collected summer, 2015 and 2017, and late summer and early fall in 2016 to conduct plant ecotoxicological assays based on plant (Lepidium, Sinapis and Sorghum) growth inhibition and identify bacterial taxonomical diversity by the $16 \mathrm{~S}$ rRNA gene sequences. Concentrations of metals such as lead $(\mathrm{Pb})$ and mercury (Hg) (using XRF), and nutrients such as nitrate and phosphate (using HACH DR $2800^{\mathrm{TM}}$ spectrophotometer) were measured in sediment and water samples respectively. Analyses of response patterns revealed that plant and bacterial bioindicators were highly responsive to variation in the concentrations of these pollutants. Hence, this opens up the scope of using these bioindicators for ecological risk assessment in constructed freshwater wetland ecosystems within urbanizing watersheds.
\end{abstract}

Keywords: bioindicators; bacterial diversity; ecotoxicology; ecological risk assessment; wetlands; land use; pollutants

\section{Introduction}

Decades of industrialization, agriculture, and urbanization have resulted in toxic discharges such as metals, petroleum products, domestic wastes, nutrients, and other pollutants finding their way into freshwater ecosystems [1,2]. Studies [1,3,4] have shown that metals and nutrients may be indicators of pollutant levels in freshwater ecosystems. Various methods, including chemical indicators, have been used as "weight of evidence" to measure the extent of risk caused by anthropogenic pollutants and stressors [1]. What is lacking in the management of freshwater ecosystems is the extensive use of diverse bioindicators and linking them to pollutants as ecological risk assessment tools.

To explore this possibility, our study examined six freshwater constructed wetlands along the Pike River, Racine, WI, USA, in the southwestern portion of the Lake Michigan watershed (Figure 1). These wetland sites, originally built between 2001 and 2008, are connected to the river, and primarily serve as stormwater retention wetlands to reduce problems related to flooding in the surrounding watershed [5-7] (Figure 1). Stormwater wetlands are designed to provide storage for controlling runoff peaks, flooding, and water quality by various treatments (e.g., settling, bacterial degradation) [8,9]. In the context of this study, the six constructed wetlands also play an important role in ameliorating water 
quality before being discharged to the Pike River, impacting ecological health. This warrants an investigation into their function and contribution to the mitigation of stormwater pollution (Figure 1) [5-7]. This investigation is especially needed because these wetlands are between 13 to 20 years old [5-7] and might not have attained the ecological functional maturity in ameliorating water quality as natural wetlands [10]. As such, a careful process needs to be developed that looks into the status of the input pollutants (such as metals and nutrients) from the surrounding watershed into the freshwater constructed wetlands, as well as the possible response from the series of bioindicators in relation to the pollutants, to understand the effect on the biota.

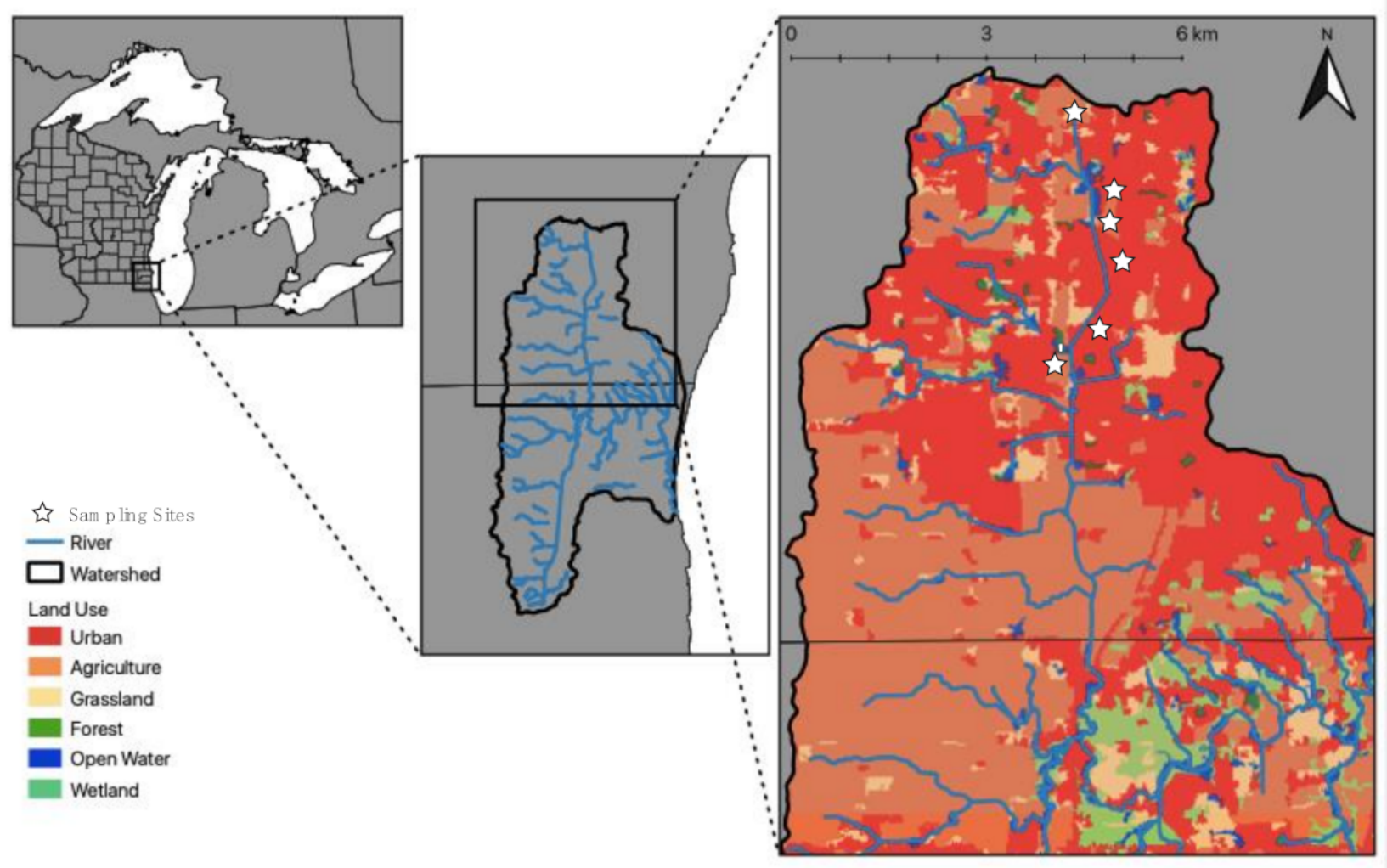

Figure 1. Map of the Pike River North Branch $\left(42^{\circ} 43^{\prime} \mathrm{N}\right.$ and $\left.87^{\circ} 52^{\prime} \mathrm{W}\right)$ displaying surrounding land use (adapted from Southeastern Wisconsin Regional Planning Commission, SEWRPC 2010). Wetland sampling sites are indicated by white stars and were numbered sequentially from 1 to 6 from north to south.

Nutrients and metals are transported to wetlands through surface flow, precipitation, groundwater, and tides [11], and microbes play an essential role in recycling and removing these elements [11,12]. Wetlands are also highly productive due to active aerobes and anaerobes [13] which quickly recycle nutrients such as nitrate and phosphate [11,12]. Studies have shown that substantial changes can occur in microbial diversity with increasing metal concentrations $[14,15]$. Metals like zinc $(\mathrm{Zn})$, arsenic (As), mercury $(\mathrm{Hg})$, and lead $(\mathrm{Pb})$ may negatively impact the bacterial community, affecting both diversity and abundance [16-20].

Recent studies illustrated the value of incorporating sediment bacterial assemblage data in monitoring the status of freshwater ecosystems [21,22]. Molecular tools like the $16 \mathrm{~S}$ rRNA gene sequencing [23] can characterize bacterial communities [24,25] relatively quickly and in detail $[24,25]$. Several studies have identified sediment communities in freshwater ecosystems using these molecular tools [2,26-29]. Even if the contamination is low, microbial indicators react to change in environmental quality and [30] signal change that might not be detectable in higher trophic level bioindicators such as animals [30]. As 
bacterial communities are quickly altered by pollutants such as nutrients and metals, the choice of these bioindicators can give a clear idea about the possible response from the biota of a constructed freshwater wetland ecosystem.

On the other hand, PhytoToxKits ${ }^{\mathrm{TM}}$ (Microbiotest Inc. 2019, Gent, Belgium) [31], measuring the growth inhibition of indicator plants, has been effective in detecting toxic hazards in reservoir sediments and urban canals subjected to varying levels of nutrients and metal contaminations [32-34]. These constructed wetlands are in a rapidly urbanizing watershed (Figure 1), so bioindicators that have already effectively detected these toxic hazards can be expected to produce a response pattern to compare with [32-35].

These six constructed wetland study sites are on a rapidly urbanized watershed. (Figure 1, Table 1). Other studies indicated the presence of metals [36] and nutrients [37] in urbanizing watersheds. Hence, both these pollutants need to be investigated to see how their presence might affect the associated biota.

Table 1. Wetland site, water quality characteristics, and organic matter (OM) percent monitored on ten separate days between June and August 2017 of wetland sites 1-6 in the Pike river watershed (adapted from [35]).

\begin{tabular}{|c|c|c|c|c|c|c|}
\hline \multicolumn{7}{|c|}{ A. Landcover (Percent in Watershed) } \\
\hline \multirow{2}{*}{ Wetland Site } & \multirow{2}{*}{$\begin{array}{l}\text { Watershed } \\
\text { Area (ha) }\end{array}$} & Percent & Percent & Percent & Percent & Percent \\
\hline & & Residential & Commercial & Industrial & Agricultural & Undeveloped \\
\hline 1 & 104.45 & 11 & 15.1 & 12.1 & 61.6 & 0 \\
\hline 2 & 334.18 & 42.3 & 0 & 0 & 57.5 & 0 \\
\hline 3 & 267.46 & 41.8 & 0 & 0 & 58.2 & 0 \\
\hline 4 & 2.88 & 58.9 & 6 & 0 & 35.2 & 0 \\
\hline 5 & 493.72 & 15.7 & 14.2 & 20.8 & 0 & 49.3 \\
\hline 6 & 720 & 0 & 72.2 & 20.2 & 0 & 7.2 \\
\hline \multicolumn{7}{|c|}{ B. Water and Sediment Characteristics } \\
\hline Wetland Site & $\begin{array}{c}\text { Median } \\
\text { Temperature } \\
\left.{ }^{\circ} \mathrm{C}\right)\end{array}$ & Median pH & $\begin{array}{c}\text { Median } \\
\text { Specific } \\
\text { Conductance } \\
(\mathrm{mS} / \mathrm{cm})\end{array}$ & $\begin{array}{c}\text { Median } \\
\text { Dissolved } \\
\text { Oxygen (\%) }\end{array}$ & $\begin{array}{c}\text { Median } \\
\text { Dissolved } \\
\text { Oxygen }(\mathrm{mg} / \mathrm{L})\end{array}$ & $\begin{array}{c}\text { Median } \\
\text { Organic Matter } \\
\text { Percent }\end{array}$ \\
\hline 1 & 21.5 & 7.6 & 870 & 105.9 & 9.2 & 8.1 \\
\hline 2 & 21.2 & 7.7 & 634 & 101.8 & 8.7 & 13.3 \\
\hline 3 & 20.2 & 7.2 & 701 & 79.2 & 6.9 & 17 \\
\hline 4 & 19.9 & 7.2 & 907 & 48.1 & 3.8 & 8.4 \\
\hline 5 & 21.4 & 7.7 & 974.5 & 88.6 & 7.8 & 3.8 \\
\hline 6 & 21.8 & 7.1 & 1395.5 & 81.5 & 7.1 & 14 \\
\hline
\end{tabular}

This study establishes an approach of using a set of bioindicators (ecotoxicological and bacterial) that are quick, responsive, and have not yet been integrated to understand the effects of pollutants on ecosystem health. These bioindicators can predict a wide range of impacts from pollutants and were applied to understand a wider extent of the ecological health risk from anthropogenic activities in freshwater constructed wetland ecosystems in an urbanizing watershed. First, the study used an ecotoxicological approach with three plant bioindicator species (Sorghum saccharatum, Lepidium sativum and Sinapis $a l b a$ ). It then focused on identifying wetland sediment bacterial taxonomic diversity by $16 \mathrm{~S}$ rRNA sequencing. Finally, the responses of the bioindicators were correlated to the measured pollutants (nutrients in the water, metals in sediments) present in the constructed freshwater wetlands. Therefore, this study meets the gap of correlating ecotoxicological and bacterial bioindicators with nutrient and metal pollutants as risk assessment measurements in freshwater ecosystems.

The study addresses the research question: does variation in the growth inhibition of plant (Sorghum, Lepidium and Sinapis) bioindicators and sediment bacterial taxonomical diversity correlate and predict response patterns with measured concentrations of nutrient 
and metal pollution (i.e., ex post impact indicators for ecological risk assessment) entering wetlands from the surrounding watershed?

\section{Materials and Methods}

\subsection{Study System, Land Use, and Site Characteristics}

This study was conducted in the Pike River Watershed (Racine County, WI, USA). This watershed has been transitioning from agricultural to (sub) urban dominant land uses over the past few decades. Due to this large-scale conversion, flooding became an emergent problem sparking the need for a large-scale restoration project. To address these flood-control issues, a set of wetlands were constructed between 2001 and 2008. Six of these constructed wetlands were selected as the sites for this study (Figure 1) [5-7]. The catchment area and percent land use data of each wetland site were extracted from the Southeastern Wisconsin Regional Planning Commission (SEWRPC) [38] (Table 1). Additionally, the mean water quality characteristics measured in the six wetland sites during summer 2017 are in Table 1.

\subsection{Sediment Sampling Collection and Water Quality Monitoring}

Sediment samples from each wetland site were collected during summer (August) 2015, fall (late August and mid September) 2016, and summer (August) 2017 using a core sampler $(5 \times 50 \mathrm{~cm})$ and Ekman dredge grab sampler $(15 \times 15 \times 25 \mathrm{~cm})$ [39]. The organic content was measured using 10-15 g of sediment sampled from each wetland site using the loss of weight upon the ignition method [40]

Water quality characteristics ( $\mathrm{pH}$, temperature, dissolved oxygen, specific conductance, and turbidity) were monitored at each site using a multi-parameter YSI 6600 sonde [41], and $1 \mathrm{~L}$ grab water samples were collected on twelve separate days between June and August 2017 for nutrient measurements. Three water quality readings and water samples were taken along a transect of each wetland site. Water samples for nutrient measurements were stored on ice and transported to the laboratory for analysis within $24 \mathrm{~h}$ of sample collection.

\subsection{Ecotoxicological Assays and Nutrient and Metal Measurements in Wetland Sites}

Ecotoxicological tests were carried out following the standard operational procedures for Phytotoxkit ${ }^{\mathrm{TM}}$ (Microbiotest Inc. 2015, Gent, Belgium) using three plant species: monocot Sorghum saccharatum and dicots Lepidium sativum and Sinapis alba [27,35]. Growth inhibition was measured after $72 \mathrm{~h}$ of growth in the sediments collected from each wetland site with respect to their growth in control sediments (washed sand-as provided in the kit) $[31,39]$.

Water samples were analyzed for nitrate and phosphate concentration with a $\mathrm{HACH}$ DR $2800^{\mathrm{TM}}$ spectrophotometer. Nitrate concentrations were analyzed using the cadmium reduction method with a detection range of $0.3-30.0 \mathrm{mg} / \mathrm{L} \mathrm{NO}^{-}{ }^{-}$[42]. Phosphate concentrations were analyzed using the ascorbic acid method with a detection range of 0.02 to $2.50 \mathrm{mg} / \mathrm{L} \mathrm{PO}_{4}{ }^{3-}$ [43]. Nutrient analyses were performed in triplicate for each sample. The mean of three readings was calculated for later analysis.

Sediment samples were tested for the presence and estimated concentration of metals $(\mathrm{Ag}, \mathrm{Hg}, \mathrm{Pb}, \mathrm{As}, \mathrm{Ni}, \mathrm{Zn}$, and $\mathrm{Cd}$ ) using X-ray fluorescence (XRF) [44-49]. After large rocks and organic debris were removed, sediment samples from each wetland site were dried at $60-80{ }^{\circ} \mathrm{C}$ until a constant weight was obtained. Dried samples were homogenized using a mechanical homogenizer and turned into $\sim 5 \mathrm{~g}$ pellets $(25 \mathrm{~mm}$ diameter and $5 \mathrm{~mm}$ height) with a 25-metric ton press pellet. XRF analyses were conducted with a Bruker Tracer III-V+ p-spectrophotometer [44-47] using the red filter to allow $\mathrm{x}$-rays from 14 to $40 \mathrm{KeV}$ to reach the sample. This filter is better for analyzing higher $\mathrm{Z}$ elements, such as heavy metals [44-49]. Three readings were taken from each sample. The mean of the three readings was calculated for later analysis. 
Calibrations were performed using the National Institute of Standards and Technology [50] standard reference materials (SRMs). These SRMs contained certified amounts of the targeted metals in soil or sediments. The SRMs were obtained from the National Institute of Standard and Technology (NIST). The XRF signal intensity was plotted against the value of each SRM to construct the calibration curves. Blank sample pellets composed of chemically pure silica were used to check for cross-contamination or other interferences. All the analyses were performed in a sample cup under the Si-Pin detector of the Bruker Tracer III-V+ p-spectrophotometer [47-49]. Three readings (in ppm) were recorded for each sample [51]. Finally, the mean of the three readings was calculated for later analysis.

\subsection{Bacterial Community Structure}

DNA was extracted using $0.8 \mathrm{~g}$ of each sediment sample with the Fast DNA ${ }^{\mathrm{TM}}$ spin kit for soil $[52,53]$. Three extractions were performed from each sample yielding $70 \mu \mathrm{L}$ of DNA suspended in DES solution, and $2 \mu \mathrm{L}$ of the extracted DNA was quantified using a Nanodrop 1000 Spectrophotometer for every extraction [54]. After $72 \mathrm{~h}, 10-20 \mu \mathrm{L}$ of the extracted DNA (the extraction with the best DNA quantity for each sample) was sent to the University of Wisconsin Madison Biotechnology Centre for library preparation and sequencing of the v3-v4 region in the 16S bacterial rRNA gene using Illumina NextGeneration Sequencing [55].

After the sequences were retrieved electronically, bioinformatics analyses were done using the software Mothur (v1.36.1). This set of analyses used the SILVA database (Release Version 128) for sequence alignment and Greengenes Reference Taxonomy (Version13_8_99) for taxonomy [56]. In Mothur, the sequences were screened to remove any with ambiguous bases longer than $464 \mathrm{bp}$. Unique sequences were then identified, and duplicates removed. Sequences were aligned as per the SILVA database (Release Version 128), with the start and end of the alignment being specified. After this, the sequences were counted, filtered, and pre-clustered, splitting the sequences by group, sorting them by abundance, listing from most to least abundant, and identifying sequences within 2 nt of each other. Chimera.vsearch was then performed to remove chimeric sequences, and the resulting sequences were classified using Greengenes Reference Taxonomy (Version13_8_99) [56].

\subsection{Data Analyses}

Data distributions were examined for normality and transformed as necessary to meet the assumptions of statistical tests. Count and length data were transformed using a log transformation, while proportional data were transformed using an arcsine transformation [57] prior to statistical analyses [58]. Bacterial taxonomical diversity from each sediment sample collected was calculated using Shannon and Simpson diversity indices for both order and genera [28].

Multifactor analysis of variance (ANOVA) was used to examine the effects of nutrients and metals on plant growth inhibition and bacterial diversity indices, respectively. The effects of measured nutrient concentrations on the plant growth inhibition and bacterial indicators were tested for samples from 2017 when in situ nutrients were measured.

Factor analysis was conducted using the log-transformed concentrations of the metals measured from the wetland sediments [57,58] with maximum likelihood and varimax rotation method based on a correlation matrix. ANOVA was used to measure the metal pollution in ppm on plant growth inhibition and bacterial diversity indices of order and genera. The year was also an independent factor in the model.

Prediction profiles were used together with multi-factor models [58] to examine how values of independent factors (either nutrients or metals) interacted to influence the growth inhibition of plants or bacterial indicators.

Finally, a forward stepwise multiple regression was used to determine the best fit model for the combined predictive linear relationships between pollutants (nutrients and metals) and growth inhibition of the ecotoxicological and bacterial bioindicators. All analyses were performed using $\mathrm{JMP}^{\circledR} 14$ [58]. 


\section{Results}

\subsection{Distribution of Measured Nutrients, Metals and Factor Analysis of the Metal Concentrations}

The measured nitrate concentrations were between 0 to $11 \mathrm{mg} / \mathrm{L}$, and the phosphate concentrations were between 0 to $1.8 \mathrm{mg} / \mathrm{L}$ across all six wetland sites water during summer 2017.

During summer 2015, early fall 2016, and summer 2017, sediment concentration of silver (Ag) ranged from 8 to $13 \mathrm{ppm}$, arsenic (As) was from 0 to $4 \mathrm{ppm}$, cadmium (Cd) was from 1.4 to $2.6 \mathrm{ppm}$, mercury $(\mathrm{Hg})$ was from 0.25 to $2.75 \mathrm{ppm}$, nickel (Ni) was from 12 to $21 \mathrm{ppm}$, lead $(\mathrm{Pb})$ was from 0.001 to $0.0035 \mathrm{ppm}$, and zinc ( $\mathrm{Zn})$ was from 5 to $40 \mathrm{ppm}$ across all six wetland sites. Factor analysis was conducted with the metal concentrations resulting in two linear components: Component 1 showed positive loadings for $\mathrm{Ag}, \mathrm{Zn}, \mathrm{As}, \mathrm{Cd}$, and $\mathrm{Ni}$ concentrations. Component 2 showed a positive loading for $\mathrm{Pb}$ and negative loading for Hg (Figure 2), suggesting that these metals were negatively associated with each other in the sediment samples.

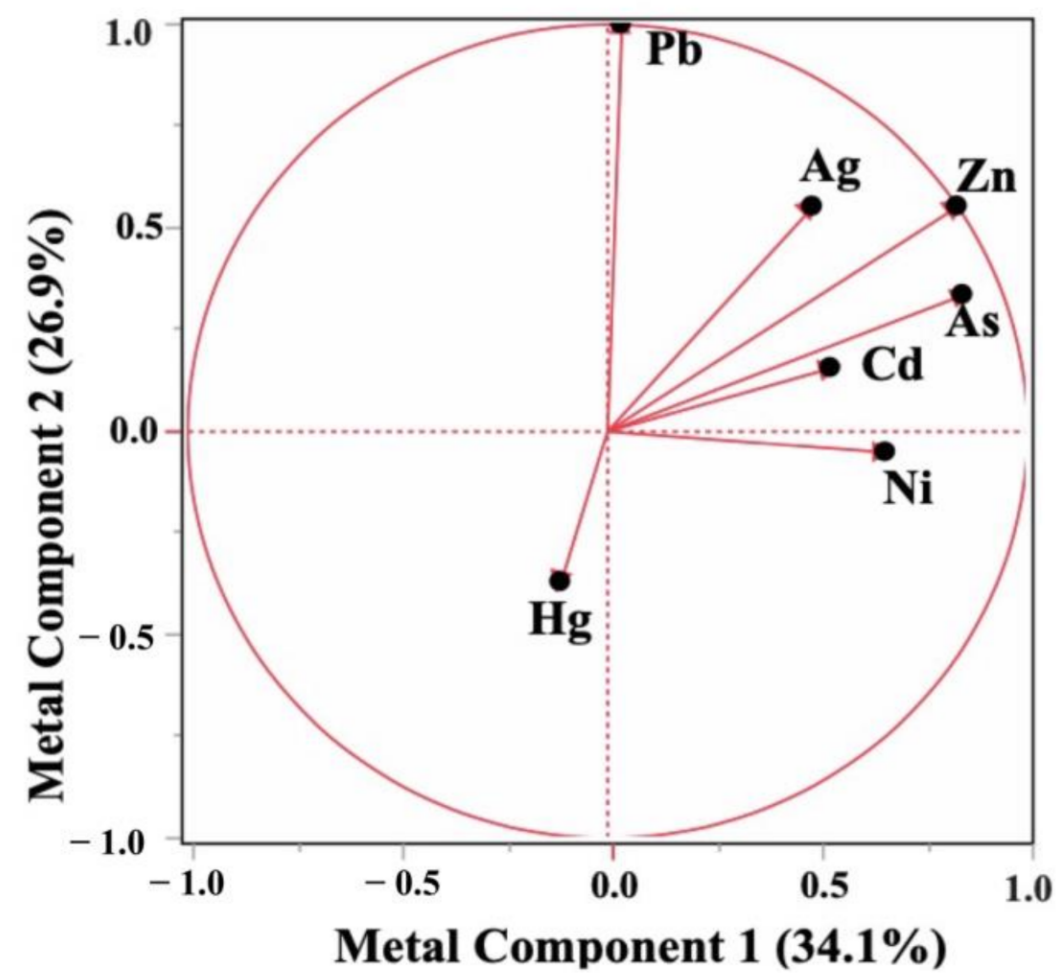

Figure 2. Component loadings from multivariate factor analysis using JMP ${ }^{\circledR} 14$ (SAS 2019). Analysis was conducted on the correlations matrix using the maximum likelihood and varimax rotation method. The XRF detected metals ( $\mathrm{Ag}, \mathrm{Zn}, \mathrm{As}, \mathrm{Cd}, \mathrm{Ni}, \mathrm{Pb}$, and $\mathrm{Hg}$ in ppm) were factored into two linear components (Component 1 and 2) which represented $61 \%$ of the total variation. Data were from sediments collected from wetland sites 1-6 sampled during 2015-2017. The plot shows rotated factor loadings relative to each component in the multivariate space.

\subsection{Ecotoxicological Indicators and Their Response to Nutrient and Metal Pollution Stress}

The proportions for root and stem growth inhibition values were calculated with respect to growth in control sediments (clean silica sand), with positive values indicating inhibition (reduced growth relative to controls) and negative values indicating stimulation (increased growth relative to controls). For Lepidium, root inhibition was in the range of -1.5 to +1.5 , and for stem inhibition, -0.75 to +1.25 . For Sinapis, root inhibition was in the range of -1.5 to +1.25 , and for stem inhibition, -1 to +1.25 . For Sorghum, the proportion 
root inhibition ranged from -1.5 to +1.25 , and stem inhibition ranged from -3.5 to +1.5 . Responses varied among wetland sites, between years of sampling and by species [39].

Multifactor analysis of variance (ANOVA) was used to examine the effects of measured nutrients on plant growth inhibition. There were different response patterns with respect to nutrients measured directly in the wetlands (Figure 3), where root inhibition was significantly affected by phosphate $(p=0.0207)$ and by its interaction with nitrate $(p=0.0190)$ (Figure 3$)$. Root inhibition increased with higher phosphate concentrations (Figure 3).

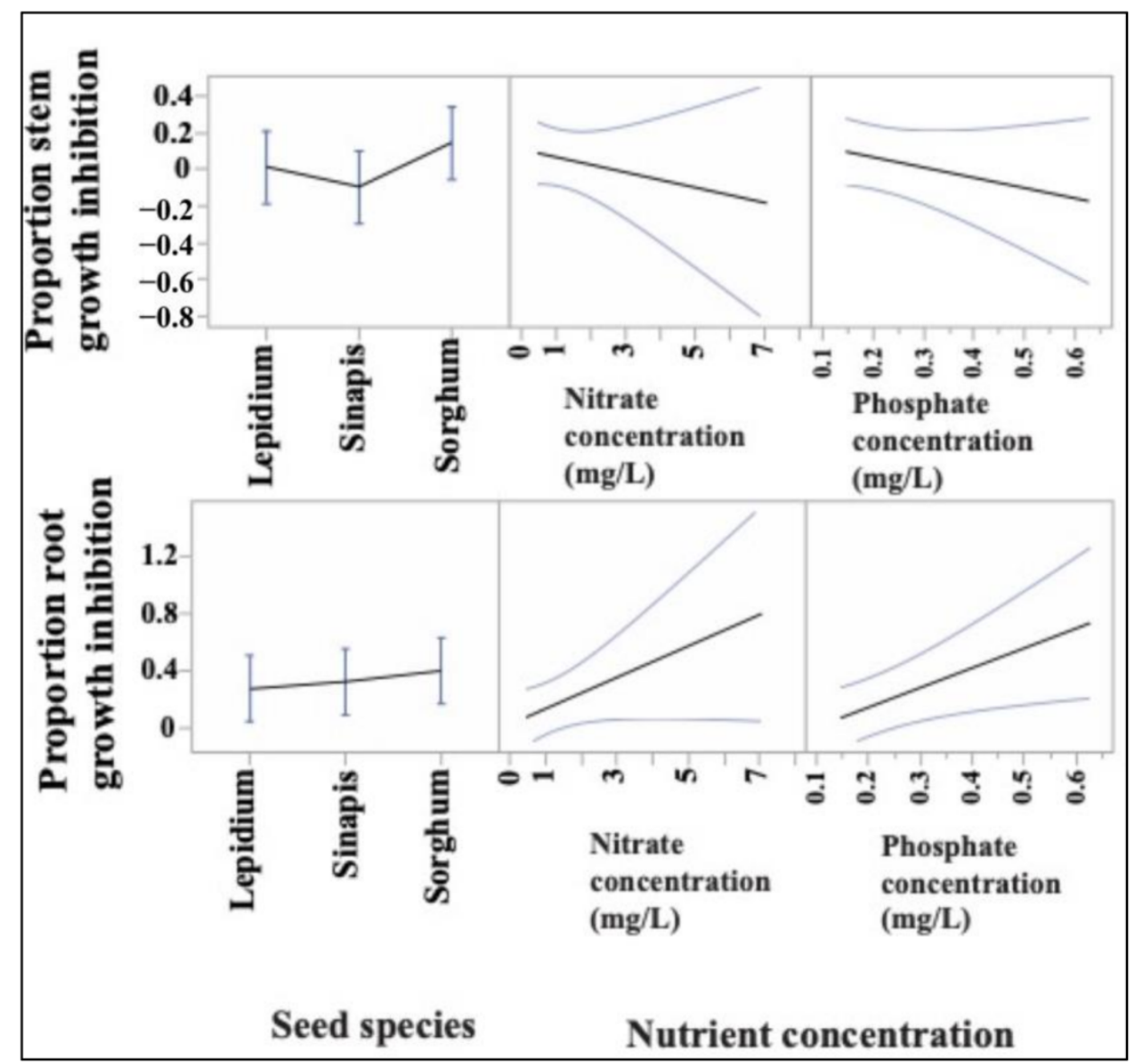

Figure 3. Prediction profiles from ANOVA showing the effects of seed species, nitrate and phosphate concentrations (mg/L) measured in wetlands on the growth inhibitions of the bioindicator species Lepidium sativum, Sinapis alba and Sorghum saccharatum. The blue-lined area in each profile represents the $95 \%$ confidence prediction interval of the $y$ (continuous) variable). The profiler was set to nitrate at $2.27 \mathrm{mg} / \mathrm{L}$ and phosphate at $0.29 \mathrm{mg} / \mathrm{L}$ in case of root and stem growth inhibition.

The effects of metal concentrations on ecotoxicological bioindicator growth inhibitions were also examined through ANOVA, using component scores calculated from the factor analysis (Figure 2). None of the metal components had a statistically significant effect on stem growth inhibition with $p$ values for metal component $1=0.3511$, component $2=0.8892$, and interaction of components $=0.5697$ (Figure 4 ). However, seed species did respond significantly $(p=0.0002)$. 


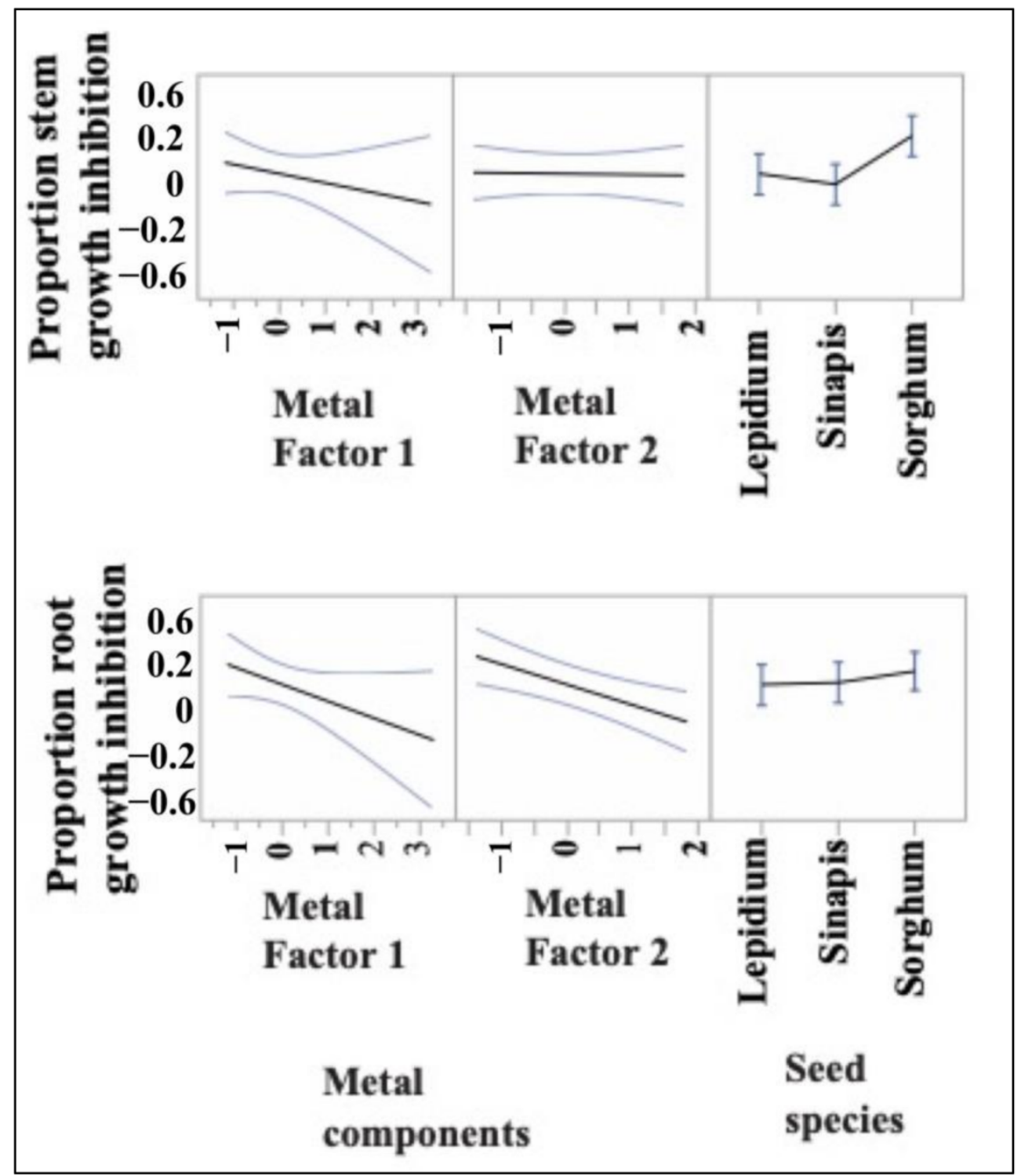

Figure 4. Prediction profiles from ANOVA showing the effects of metal components 1 and 2 (from factor analysis) on the growth inhibitions of the bioindicator species Lepidium sativum, Sinapis alba and Sorghum saccharatum. The blue-lined area in each profile represents the $95 \%$ confidence interval for the prediction of the response variable. The profiler was set to metal component 1 at 1.0 and metal component 2 at 0.75 in case of root and stem growth inhibition.

While metal pollutants did not have a significant relationship with stem growth inhibition, root inhibition was affected significantly. The positive axis of metal component 2 in the factor analysis was associated with higher $\mathrm{Pb}$ and lower $\mathrm{Hg}$ concentrations (Figure 2). The negative axis of metal component 2 of the factor analysis was associated with lower $\mathrm{Pb}$ and higher $\mathrm{Hg}$ concentrations (Figure 2). An increase in metal component 2 (positive axis) showed a significant decrease in root inhibition ( $p=0.0026$, Figure 4$)$. The negative axis of metal component 2 (lower $\mathrm{Pb}$ and higher $\mathrm{Hg}$ concentrations) was associated with increased root inhibition ( $p=0.0026$, Figure 4$)$.

Finally, a stepwise multiple regression model was calculated to predict the responses of ecotoxicological bioindicators in relation to nutrients (nitrate and phosphate) and metals ( $\mathrm{Hg}$ and $\mathrm{Pb}$ ). Each plant bioindicator species was run separately for nutrients (2017 data only) and metals (2015-2017 data). Best fit models using the forward stepping algorithm are presented in Table 2. Lepidium stem inhibition exhibited no significant response to variation 
in nutrients or metals (Table 2). Sinapis stem inhibition had a positive relationship with nitrate but a negative relationship with phosphate, with a total $\mathrm{R}^{2}$ of 0.84 (Table 2). Sorghum stem inhibition exhibited a negative association with nitrate but a positive relationship with phosphate. Sorghum also had a positive relationship with $\mathrm{Pb}$ and $\mathrm{Hg}$ with an overall $\mathrm{R}^{2}$ of 0.96 (Table 2). For root inhibition, Lepidium growth inhibition was associated positively with nitrate and negatively with $\mathrm{Pb}$ and $\mathrm{Hg}$, with an overall $\mathrm{R}^{2}$ of 0.82 (Table 2). Sinapis root inhibition was negatively associated with $\mathrm{Pb}$ and $\mathrm{Hg}$, with an overall $\mathrm{R}^{2}$ of 0.55 (Table 2). For Sorghum, root inhibition had a negative estimated relationship with $\mathrm{Pb}$, with an overall $\mathrm{R}^{2}$ of 0.39 (Table 2).

Table 2. Stepwise regression with the estimates of the relationship between nutrient (nitrate and phosphate concentration in $\mathrm{mg} / \mathrm{L})$ and metal $(\mathrm{Hg}, \mathrm{Pb})$ concentration in $\mathrm{ppm}$ with stem and root growth inhibition of Lepidium sativum, Sinapis alba and Sorghum sachharatum in wetland sites $1-6$, along with appropriate $\mathrm{R}^{2}$ and $p$ values. The blank spaces revealed no estimates of relationship.

$\begin{array}{llllll}\text { Seed Species } & \text { Nitrate } & \text { Phosphate } & \mathrm{Pb} & \mathrm{Hg} & \mathbf{R}^{2}\end{array}$

(A) Stem Inhibition

\begin{tabular}{|c|c|c|c|c|c|}
\hline \multicolumn{6}{|l|}{ Lepidium } \\
\hline Sinapis & $\begin{array}{c}0.31 \\
(p=0.0656)\end{array}$ & $\begin{array}{c}-1.96 \\
(p=0.0286)\end{array}$ & & & 0.84 \\
\hline Sorghum & $\begin{array}{c}-1.77 \\
(p=0.1249)\end{array}$ & $\begin{array}{c}1.88 \\
(p=0.2417)\end{array}$ & $\begin{array}{c}998.83 \\
(p=0.1879)\end{array}$ & $\begin{array}{c}4.80 \\
(p=0.1548)\end{array}$ & 0.96 \\
\hline Seed Species & Nitrate & Phosphate & $\mathrm{Pb}$ & $\mathrm{Hg}$ & $\mathrm{R}^{2}$ \\
\hline Lepidium & $\begin{array}{c}2.12 \\
(p=0.0998)\end{array}$ & & $\begin{array}{c}-1559.8 \\
(p=0.1216)\end{array}$ & $\begin{array}{c}-6.75 \\
(p=0.1310)\end{array}$ & 0.82 \\
\hline Sinapis & & & $\begin{array}{c}-1011 \\
(p=0.1962)\end{array}$ & $\begin{array}{c}-2.46 \\
(p=0.1196)\end{array}$ & 0.55 \\
\hline Sorghum & & & $\begin{array}{c}-234.54 \\
(p=0.0031)\end{array}$ & & 0.39 \\
\hline
\end{tabular}

\subsection{Sediment Bacterial Bioindicators and Response to Nutrient and Metal Pollution}

A total of 67,503 sequences were identified from all wetland sites. The lowest number of sequences identified in a sample was 115, while the highest was 16,005. At the broadest level, 261 unique orders and 924 unique genera were identified. These unique orders and genera were used to calculate the bacterial indicators (Shannon and Simpson diversity indices of order and genera) across all six wetland sample sites. Across all sites and sampling times, the Shannon diversity index of orders ranged between 1.38 and 4.46 and the Simpson diversity index of orders ranged from 0.46 to 1.90 . The Shannon diversity index of genera ranged between 1.30 and 5.18 and the Simpson diversity index of genera ranged from 0.64 to 0.99 .

Some of the most abundant orders across all wetland sites and sampling times (summer 2015, fall 2016, and summer 2017) included: Bacillales, Bacteroidales, Clostridiales, Actinomycetales, Burkholderiales, Rhizobiales, Pseudomonadales, and Xanthomonadales (Table A1, Appendix A). Some of the most abundant genera across all wetland sites and sampling times (summer 2015, fall 2016, and summer 2017) included: Bacillus, Clostridium, Pseudomonas, Flavobacterium, Treponema, Thiobacillus, Crenothrix, Streptococcus, Bdellovibrio, and Pelomonas (Table A1, Appendix A).

The presence of potential bias in the diversity indices related to the number of $16 \mathrm{~S}$ rRNA gene sequences retrieved was analyzed for each of the wetland sites. The slope values for the following relationships with respect to the total number of sequences retrieved were calculated: Shannon diversity indices of order (slope $=0.9132, \mathrm{R}^{2}=0.3661, p=0.0218$ ), Simpson diversity indices of order (slope $=0.0848, \mathrm{R}^{2}=0.1492, p=0.6159$ ), Shannon diversity indices of genera (slope $=0.443, R^{2}=0.0701, p=0.3602$ ), and Simpson diversity indices of genera (slope $=0.0557, \mathrm{R}^{2}=1597, p=0.1568$ ) (Figure A1, Appendix B). 
Multifactor analysis of variance (ANOVA) was used to examine the effects of measured nutrients on bacterial diversity indices. The effects of measured nutrient concentrations in the wetlands on bacterial diversity indices are shown in Figures 5 and 6 . The Shannon diversity of order decreased significantly with increasing phosphate $(p<0.0001)$ and nitrate $(p=0.0299)$ concentrations (Figure 5). The nutrient interaction effect $(p=0.0032)$ was also significant on the Shannon diversity of order. The Simpson diversity index of order decreased significantly with increasing nitrate $(p<0.0001)$ and phosphate concentrations $(p<0.0001)$. A strong interaction effect of nutrients $(p<0.0001)$ (Figure 5$)$ was observed on the Simpson diversity index of order.

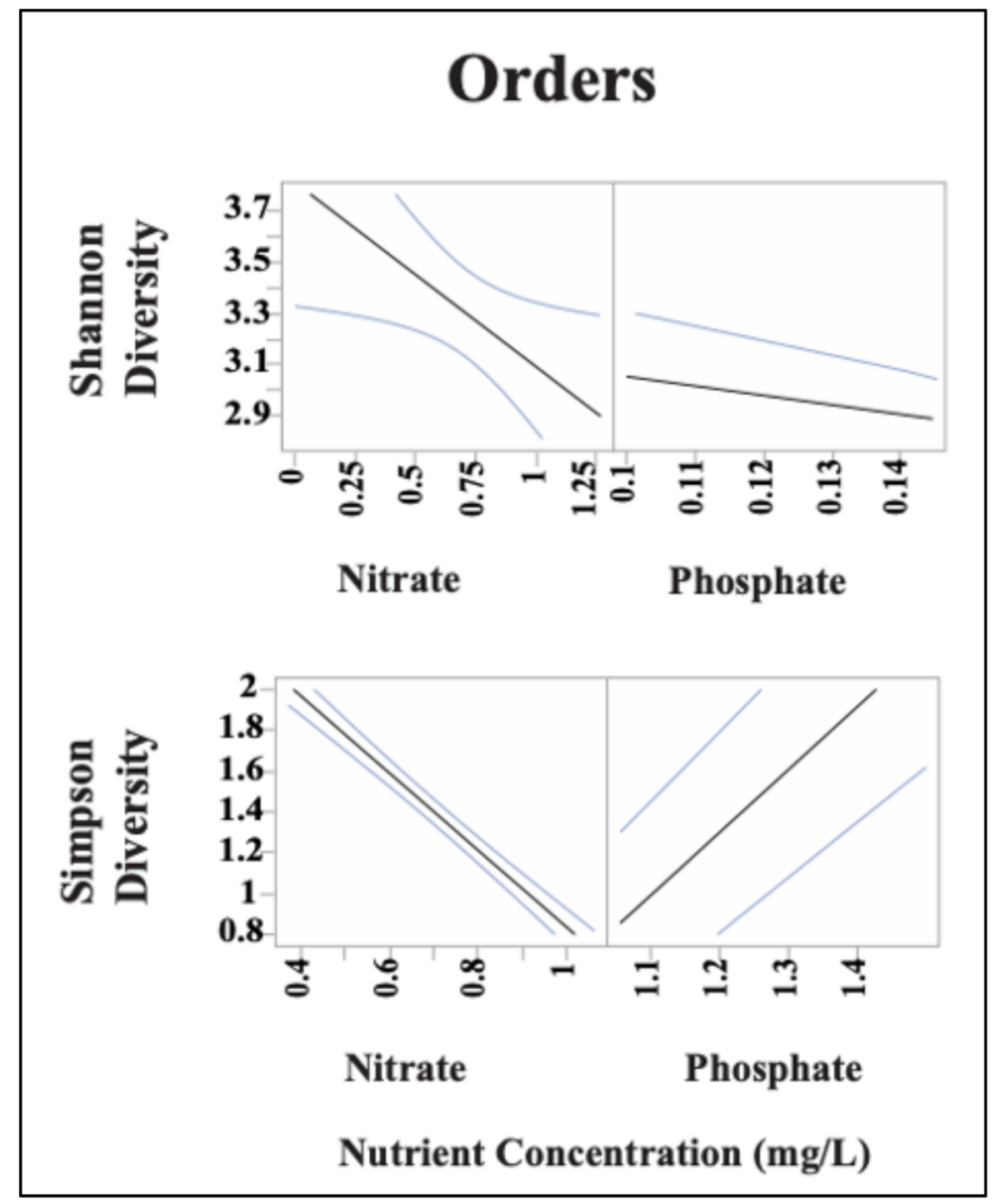

Figure 5. Prediction profiles from ANOVA, showing the effect of measured nitrate and phosphate concentration $(\mathrm{mg} / \mathrm{L})$ on the Shannon and Simpson diversity indices identified as taxonomic order out of wetland sites 1-6 during summer 2017. The blue-lined area in each profile represents the 95\% confidence prediction interval of the response variable. The profiler was set for median ambient conditions, with 2.19 nitrate at $\mathrm{mg} / \mathrm{L}$ and phosphate at $0.27 \mathrm{mg} / \mathrm{L}$ in the case of Shannon and Simpson diversity, respectively. 


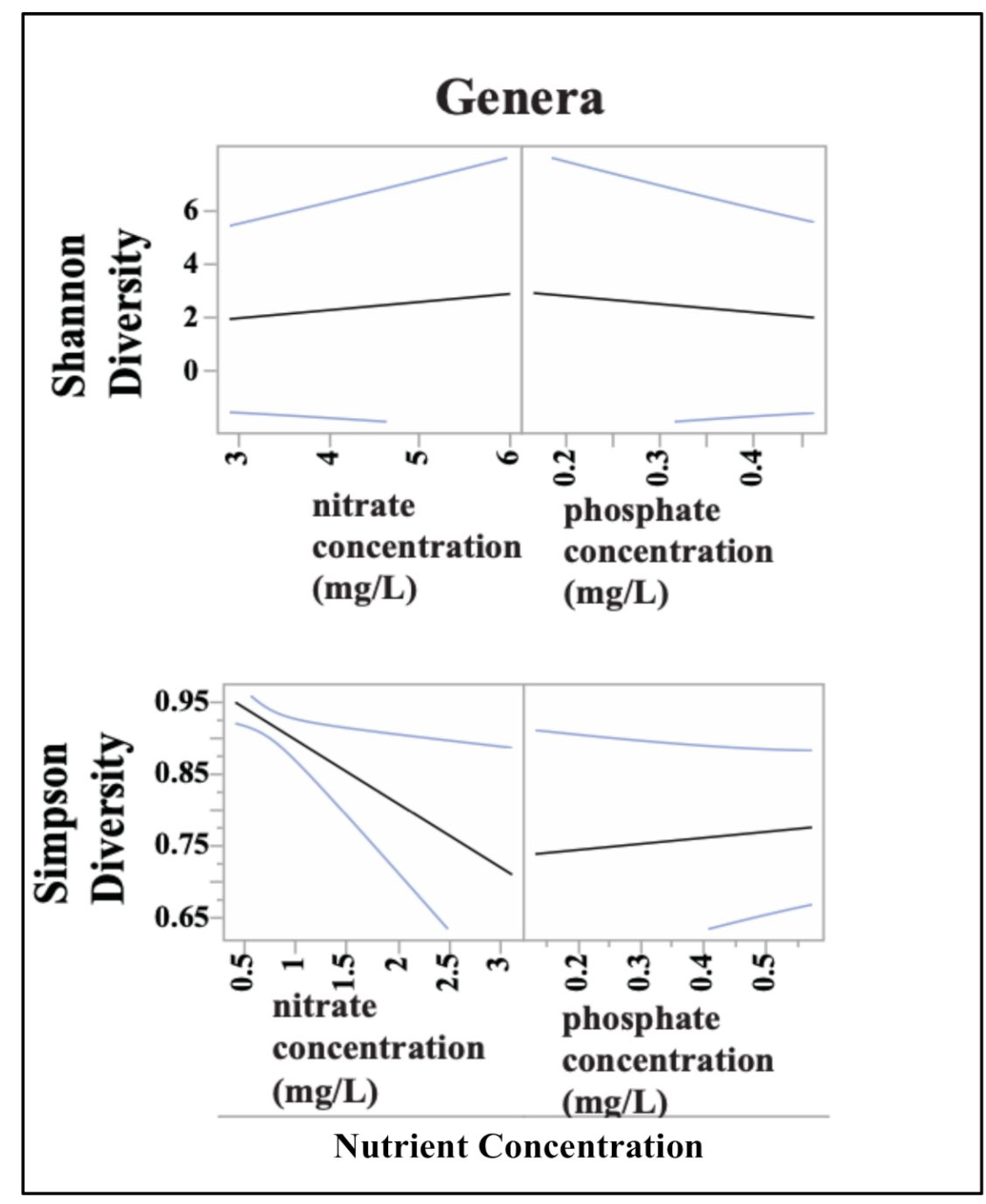

Figure 6. Prediction profiles from ANOVA, showing the effect of measured nitrate and phosphate concentration $(\mathrm{mg} / \mathrm{L})$ on the Shannon and Simpson diversity indices identified as taxonomic genera out of wetland sites 1-6 during summer 2017. The blue-lined area in each profile represents the 95\% confidence prediction interval of the response variable. The profiler was set for nitrate at $2.72 \mathrm{mg} / \mathrm{L}$ and phosphate at $0.49 \mathrm{mg} / \mathrm{L}$ in the case of Shannon diversity, and nitrate at $2.60 \mathrm{mg} / \mathrm{L}$ and phosphate at $0.32 \mathrm{mg} / \mathrm{L}$ in the case of Simpson diversity.

For bacterial genera, the Shannon diversity index of genera decreased significantly with increasing phosphate concentrations $(p=0.0266)$. However, no significant effect was observed for nitrate $(p=0.7033)$ or nutrient interactions $(p=0.3604)$ (Figure 6). The Simpson diversity index of genera was observed to decrease significantly with increasing nitrate $(p=0.0215)$. No significant effect of phosphate $(p=0.1673)$ was observed on the Simpson diversity index of genera. A strong interaction effect of nutrients $(p=0.0087)$ (Figure 6$)$ was seen on the Simpson diversity index of genera.

The effects of metal concentrations on bacterial diversity indices parameters were examined through ANOVA, using component scores calculated from the factor analysis (Figure 2). The metal component 1 (increased concentrations of As, Ag, Cd, Ni, and $\mathrm{Zn}$ in $\mathrm{ppm}$ ) had a significant effect on the Shannon diversity index of order $(p=0.0801)$, and the Simpson diversity index of order $(p<0.0001)$ (Figure 7). With an increase in metal component 1 , an increase in the Shannon diversity index of order and decrease in the Simpson diversity index of order was observed (Figure 7). By contrast, an increase in metal component 2 (interpreted as associated higher $\mathrm{Pb}$ and lower $\mathrm{Hg}$ concentrations) was 
associated with an increase in the Shannon diversity index of order $(p<0.0001)$, and the Simpson diversity index of order $(p=0.0085)$ (Figure 7). The interaction effect of metal components 1 and 2 had a significant effect on both the Shannon $(p<0.0001)$ and Simpson $(p=0.0084)$ diversity indices of order (Figure 7).

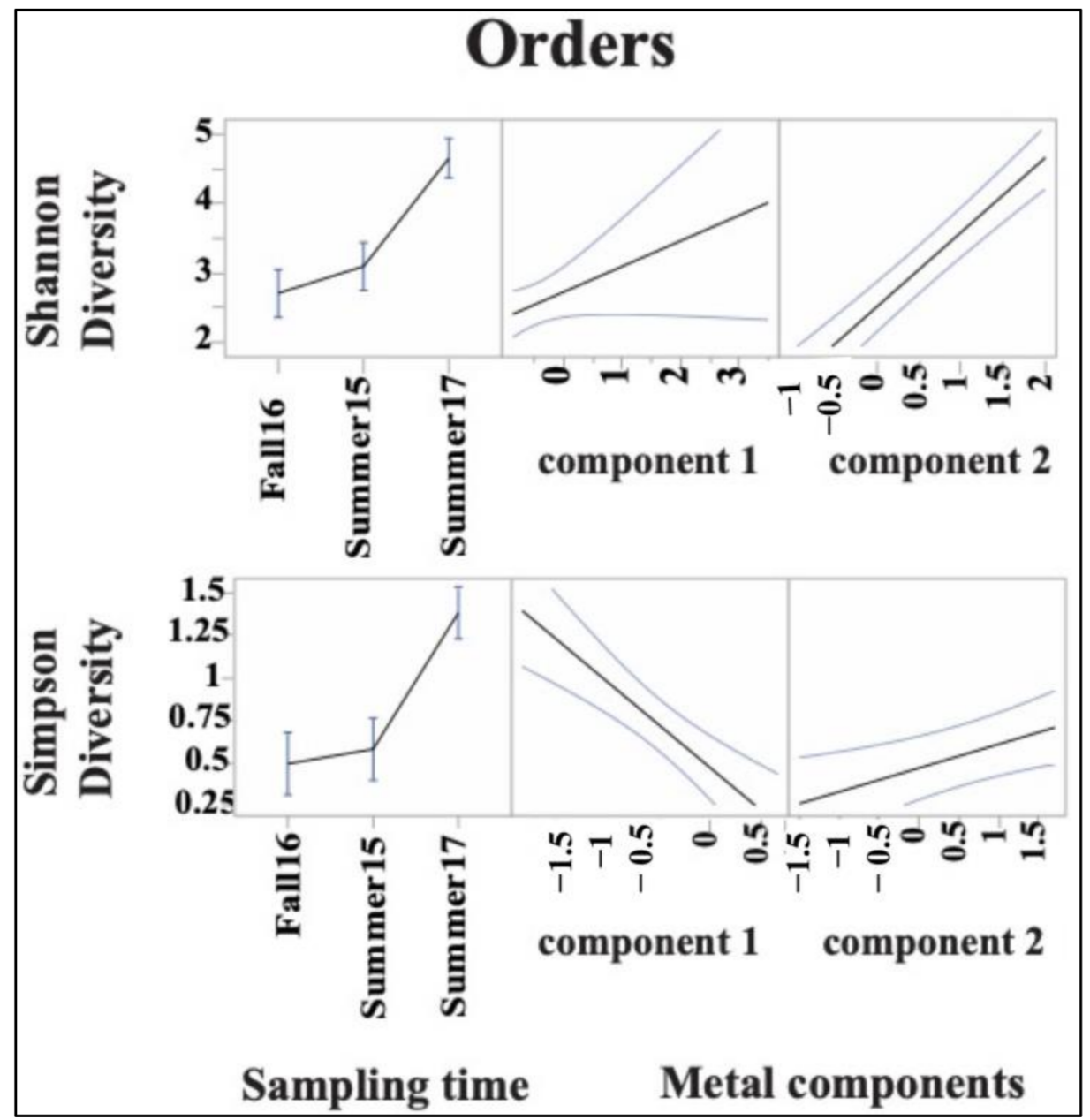

Figure 7. Prediction profiles from ANOVA showing the effect of metal component 1 and 2 (from principal component analysis) on the Shannon and Simpson diversity indices identified as taxonomic order from wetland sites 1-6 during fall 2016 and summer 2015 and 2017. The blue-lined area in each profile represents the $95 \%$ prediction confidence interval of the response variable. The profiler was set to metal component 1 at -0.0516 and metal component 2 at 0.1825 in the case of Shannon and Simpson diversity, respectively.

Metal component 1 did have a significant effect on the Shannon diversity index of genera $(p=0.0413)$, but not on the Simpson diversity index of genera $(p=0.0945)$ (Figure 8$)$. With an increase in metal component 1 , the Shannon diversity index of genera decreased (Figure 8). The Simpson diversity index of genera $(p<0.0001)$ increased with the increase in metal component 2 (interpreted as associated higher $\mathrm{Pb}$ and lower $\mathrm{Hg}$ concentrations), but no significantly relationship was seen with the Shannon diversity index of genera $(p=0.5952)$ (Figure 8). The statistical interactions among metal components 1 and 2 also had a significant effect on the Simpson diversity $(p<0.0001)$ but not on the Shannon diversity of genera $(p=0.072)$. 


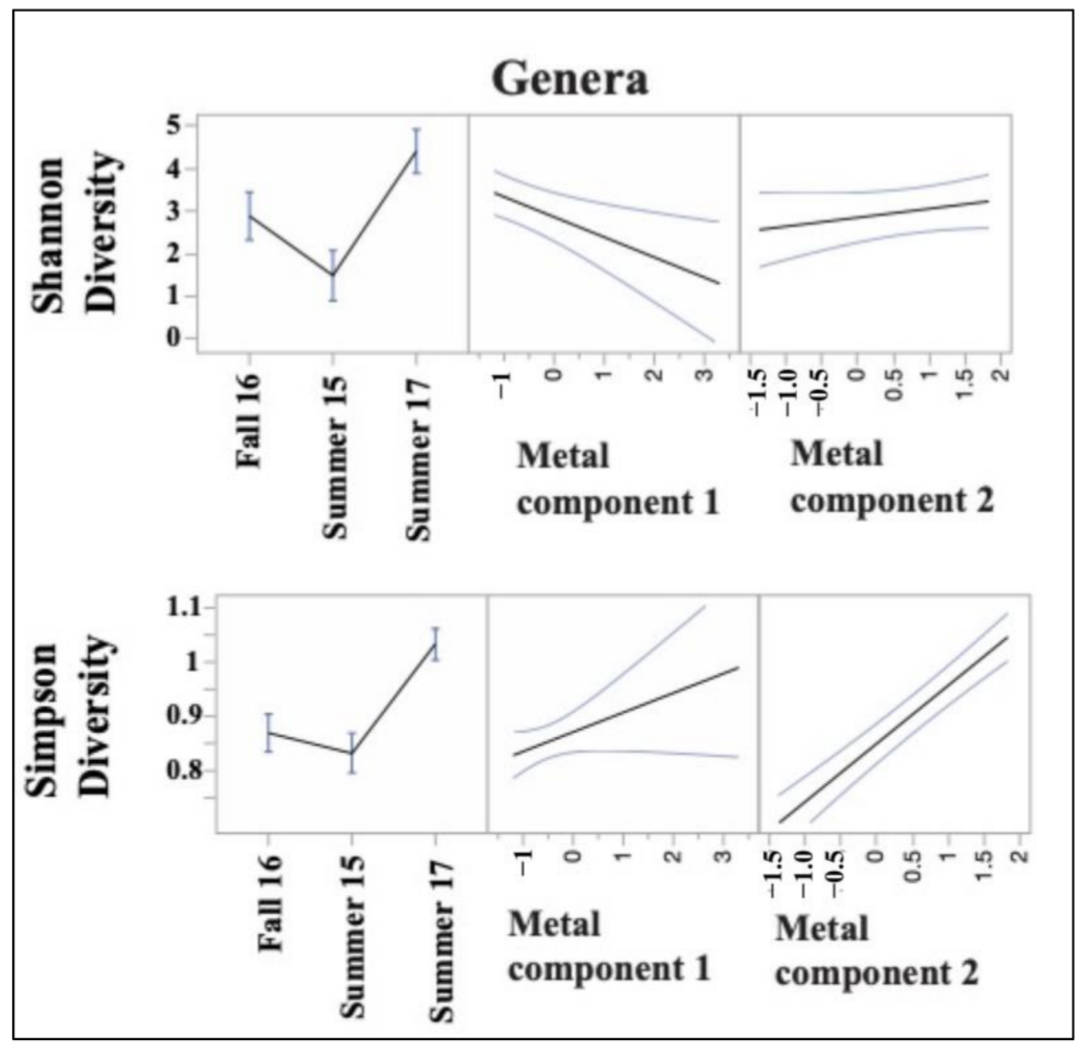

Figure 8. Prediction profiles from ANOVA showing the effect of metal component 1 and 2 (from principal component analysis) on the Shannon and Simpson diversity indices identified as taxonomic genera from wetland sites 1-6 during fall 2016 and summer 2015 and 2017. The blue-lined area in each profile represents the $95 \%$ prediction confidence interval of the response variable. The profiler was set to metal component 1 at 0.65 and metal component 2 was set to 0.18 in the case of both Shannon diversity and Simpson diversity.

Finally, a stepwise multiple regression model was calculated to predict the responses of bacterial bioindicators in relation to nutrients and metals. The metals $\mathrm{Pb}, \mathrm{Hg}, \mathrm{As}$, and $\mathrm{Zn}$ concentrations were selected for multiple regression analysis due to their high loadings in the metal factor analysis (Figure 2). The Shannon diversity index of order was associated positively with $\mathrm{Hg}$ and $\mathrm{Pb}$ (Table $3, \mathrm{R}^{2}=0.33$ ). The Shannon diversity index of bacterial genera was associated positively with $\mathrm{Hg}$ and $\mathrm{As}$ and negatively with $\mathrm{Pb}$ $\left(\mathrm{R}^{2}=0.52\right.$, Table 3$)$. The Simpson diversity index of genera was associated positively with $\mathrm{Hg}$ and $\mathrm{Pb}\left(\mathrm{R}^{2}=0.27\right.$, Table 3$)$.

Table 3. Stepwise regression with the estimates of relationship between metals concentrations with the highest loadings from factor analysis ( $\mathrm{As}, \mathrm{Zn}, \mathrm{Hg}, \mathrm{Pb}$ ) regressed against the Shannon diversity index, Simpson diversity index and total number of identified phyla and genera in wetland sites $1-6$, including $p$-values and total $R^{2}$ for the regression.

\begin{tabular}{|c|c|c|c|c|c|}
\hline & As & $\mathrm{Zn}$ & $\mathrm{Hg}$ & $\mathbf{P b}$ & $\mathbf{R}^{2}$ \\
\hline $\begin{array}{l}\text { (A) Order Shannon } \\
\text { diversity index }\end{array}$ & & & $\begin{array}{c}3.76 \\
(p=0.0084)\end{array}$ & $\begin{array}{c}1794.42 \\
(p=0.00169)\end{array}$ & 0.33 \\
\hline $\begin{array}{l}\text { (B) Order Simpson } \\
\text { diversity index }\end{array}$ & & & & & 0 \\
\hline & As & $\mathrm{Zn}$ & $\mathrm{Hg}$ & $\mathrm{Pb}$ & $\mathbf{R}^{2}$ \\
\hline $\begin{array}{l}\text { (D) Genera Shannon } \\
\text { diversity index }\end{array}$ & $\begin{aligned} & 5.53 \\
(p= & 0.00022)\end{aligned}$ & & $\begin{array}{c}11.0024 \\
(p=0.00001)\end{array}$ & $\begin{array}{c}-1845.24 \\
(p=0.0066)\end{array}$ & 0.52 \\
\hline $\begin{array}{l}\text { (E) Genera Simpson } \\
\text { diversity index }\end{array}$ & & & $\begin{aligned} & 0.36 \\
(p= & 0.01618)\end{aligned}$ & $\begin{array}{c}161.35 \\
(p=0.00595)\end{array}$ & 0.27 \\
\hline
\end{tabular}




\section{Discussion}

The study investigated the correlation and specific response patterns of plants' bioindicator growth inhibition and sediment bacterial taxonomic diversity with nutrients and metals entering into freshwater constructed wetlands from the surrounding watershed.

\subsection{Specific Response Patterns of Ecotoxicological Bioindicators to Nutrient and Metal Pollution Stress}

Factor analysis revealed significant effects of associated groups of metals (component 2: $\mathrm{Pb}$ and $\mathrm{Hg}$ ) (Figure 2). Especially in the negative axis of metal component 2, the combination of decreasing $\mathrm{Pb}$ and increasing $\mathrm{Hg}$ (Figure 2) was associated with increased root inhibition (Figure 4). The regression analysis also suggested a negative estimated relationship between $\mathrm{Hg}$, a chemical of concern often released into the environment through industrial pollution, mining, and the burning of fossil fuels [53,54], and the root growth inhibition of two of the three plant bioindicator species (Table 2 and Figure 4). Experiments have shown that $\mathrm{Hg}$ causes reduced growth in the root and stem of seedlings [59] due to the production of reactive oxygen species (ROS), causing damage in the cell membranes, chloroplast pigments, and nucleic acids [60,61].

In factor analysis, the root growth inhibition of plant bioindicators decreased in association with increased $\mathrm{Pb}$ (Figure 4), but in regression analysis, a negative estimated relationship with Lepidium, Sinapis, Sorghum, and $\mathrm{Pb}$ was observed (Table 2). This suggests that the metal factor analysis alone was not able to depict the individual interplay of the $\mathrm{Pb}$ concentration with the plant indicators clearly, and that different statistical tests can reveal a more robust risk assessment.

Agricultural and residential land uses produce runoff rich in nutrients such as phosphate and nitrate due to fertilizers and pesticides in lawns, gardens, and agricultural fields [62]. Our results indicate that high phosphate is associated with higher growth inhibition (Figure 3), which was surprising since phosphate deficiency reportedly causes growth inhibition in plants [63]. This suggests that there were interactions between nutrients (e.g., from fertilizers) and metals (e.g., from pesticides). This became evident in the regression analysis, where phosphate did not have a significant association with the root growth inhibition of the plant bioindicators when analyzed individually (Table 2).

The metal component 1 of the factor analysis had positive loadings for an array of metals Ni, Cd, As, and Zn (Figure 2), which had a modest impact on growth inhibition (Figure 4). Our previous studies performed on textile-dye-contaminated soils in India [35] demonstrated that a combination of metals present in a soil ecosystem could affect the plant bioindicator species. This study's results are consistent with a combination of metals interacting to have a toxic effect on bioindicator plant species [35].

The regression analyses for each plant bioindicator also revealed different relationships between inhibition and facilitation when analyzed for the effects of nutrient and metal pollution (Table 2). The reasons contributing to different responses by different ecotoxicological bioindicator species are grounds for further study. Herbicides and metals are well-known to affect the growth and development of Sorghum [64,65]. In comparison to Sinapis and Lepidium, the Sorghum frequently exhibited negative inhibition (facilitation) in this study.

\subsection{Bacterial Bioindicators}

Analyses of extracted DNA from sediment collected from the six wetlands over the study period demonstrated a large variety in the bacterial community assemblages. The most commonly found orders across all sampling sites over time were: Bacillales, Bacteroidales, Clostridiales, Actinomycetales, Burkholderiales, Rhizobiales, Pseudomonadales, and Xanthomonadales (Table A1, Appendix A). These results are consistent with other published studies concerning bacterial community diversity in wetland soils or sediment [66-72]. 
The Shannon and Simpson diversity indices were used in this study to calculate the diversity matrices of the bacterial population. It is advisable to include multiple indices when attempting to characterize differences in community composition [73]. The use of various indices avoids bias towards the richness or abundance of the identified operational taxonomic units (OTUs). The Shannon and Simpson diversity indices have been used previously for characterizing bacterial communities [5], and each provides somewhat different information. The Shannon diversity index is more sensitive to the taxonomic richness, resulting in identifying each unique OTU, adding to the index value evenness [73]. By comparison, the Simpson diversity index is weighted towards the most abundant OTU of a sample $[73,74]$. Moreover, in this study, the wide range of variation of the indices for both order and genera across all the wetland sites demonstrated variations in bacterial community assemblages - a primary consideration when selecting good sub-metrics for indicators [75].

It is also essential to recognize if the number of sequences detected influences the diversity indices. In this study, the correlations between the total number of sequences in the sample and Shannon diversity index of order were only significant $(p=0.0218)$ with an $\mathrm{R}^{2}$ value of 0.36 (Figure A1, Appendix B). This suggests that the number of sequences found in the wetland samples affected the order diversity more than the genera. However, with the low $\mathrm{R}^{2}$ value found between the total number of sequences in the sample and the Shannon diversity index of order as stated indicates that a relationship is not strongly present.

Generally, the Shannon diversity index ranges between 1.5 and 3.5, while the Simpson diversity index ranges from 0 to 1 [76]. In this study, the Shannon diversity indices of order and genus were 1.38-4.46 and 1.30-5.18, respectively (Figure A1, Appendix B). Other studies reported the Shannon diversity indices ranging between 3.57 and 5.38 [7,77] (Figure A1, Appendix B). The Simpson diversity index of order and genera ranged between 0.8 and 1 (Figure A1, Appendix B), in this study. Other studies reported the Simpson diversity indices between $0.46-1[77,78]$. The value of Simpson diversity was mainly in the higher range; this shows the applicability of the Simpson diversity index more in this study compared to the Shannon.

Specific Response Patterns of Bacterial Bioindicators to Nutrient and Metal Pollution Stress

This study detected an array of significant relationships between nutrients and sediment bacterial communities. The Simpson diversity of order and genera were observed to decrease with increasing measured nitrate concentration (Figures 5 and 6). Fertilizers and pesticides from surrounding agricultural and residential lands are rich in phosphate and nitrate, serving as a source of nutrients that may run off into these wetland sites $[79,80]$. There are interactions between the loadings of nutrients (e.g., from fertilizers) and loadings of other pollutants, such as metals associated with pesticides, causing less bacterial diversity.

Studies have shown that microbial diversity can substantially change in response to increasing metal concentrations [15,16], even leading to extinction [17]. Examination of metal component 2 suggests that the negative axis with metal component 2 (decreasing Pb and increasing $\mathrm{Hg}$ ) (Figure 2) was associated with reduced bacterial diversity (Figures 7 and 8). Studies indicate that most heavy metals, including $\mathrm{Hg}$, can cause toxic effects on bacterial cells at low concentrations [81,82]. However, the multiple regression analysis showed that $\mathrm{Pb}, \mathrm{Hg}$, As, and $\mathrm{Zn}$ concentrations had a significant positive relationship with the bacterial diversity indices in certain instances (Table 3). Bacterial communities have shown the ability to develop metal resistance when exposed for long durations, resulting in a positive relationship of bacterial indicators with concentrations of metals such as $\mathrm{Pb}$ and $\mathrm{Hg}$ [83-90]. The results of this study suggest that this may be occurring in the constructed wetlands. The metal component analysis revealed the effect of interactions of metals like $\mathrm{Pb}$ and $\mathrm{Hg}$ on bacterial indicators. In contrast, the regression analysis showed how the metals $(\mathrm{Pb}$ and $\mathrm{Hg}$ ) affected the bacterial indicators when analyzed individually (but concurrently with metals like As and $\mathrm{Zn}$ ). 
One of the challenges for monitoring environmental impacts is identifying and developing indicators that can capture and integrate the effects of pollutants or stressors across various (sometimes mismatched) spatial and temporal scales. For example, chronic stressors such as baseline nutrient loading from agricultural fields provide different signals than acute events such as a manure spill or pesticide application, whose detection by direct chemical measurement may be missed between monitoring sessions. To this point, robust multi-metric indicators must be constructed to include an array of biological sub-metrics that can detect biological responses to human activities across spatial and temporal scales [75]. The situation is made more complicated because interactions among different stressors in nature may result in complex response patterns that can result in the interpretation of the patterns detected being very context-dependent.

In this regard, prediction profiles provide a valuable tool for visualizing the complexity of interactions among pollutants and understanding why a single relationship for a single indicator is not sufficient in characterizing a biological response signature. An example demonstrating the interaction effect of metal factors on root inhibition is shown in Figure 9. The top half shows the expected relationship between root inhibition and metal component 1 when metal component 2 is set to a value of 1.5 , which would indicate high levels of $\mathrm{Pb}$ and low $\mathrm{Hg}$ (Figure 9A). In this case, the prediction is that one would expect to see at most a small positive effect, if any, of the increasing levels of metal component 1 on root inhibition. By contrast, the prediction profile shown in Figure 9B illustrates the predicted changes in root inhibition relative to changing levels of metal component 1 when the level of metal component 2 is held to -1.0 (low $\mathrm{Pb}$ with high $\mathrm{Hg}$ ). In this circumstance, the slope of the relationship between root inhibition and metal component 1 is negative, where increasing levels of metal component 1 are predicted to result in lower levels of root inhibition (Figure 9B).

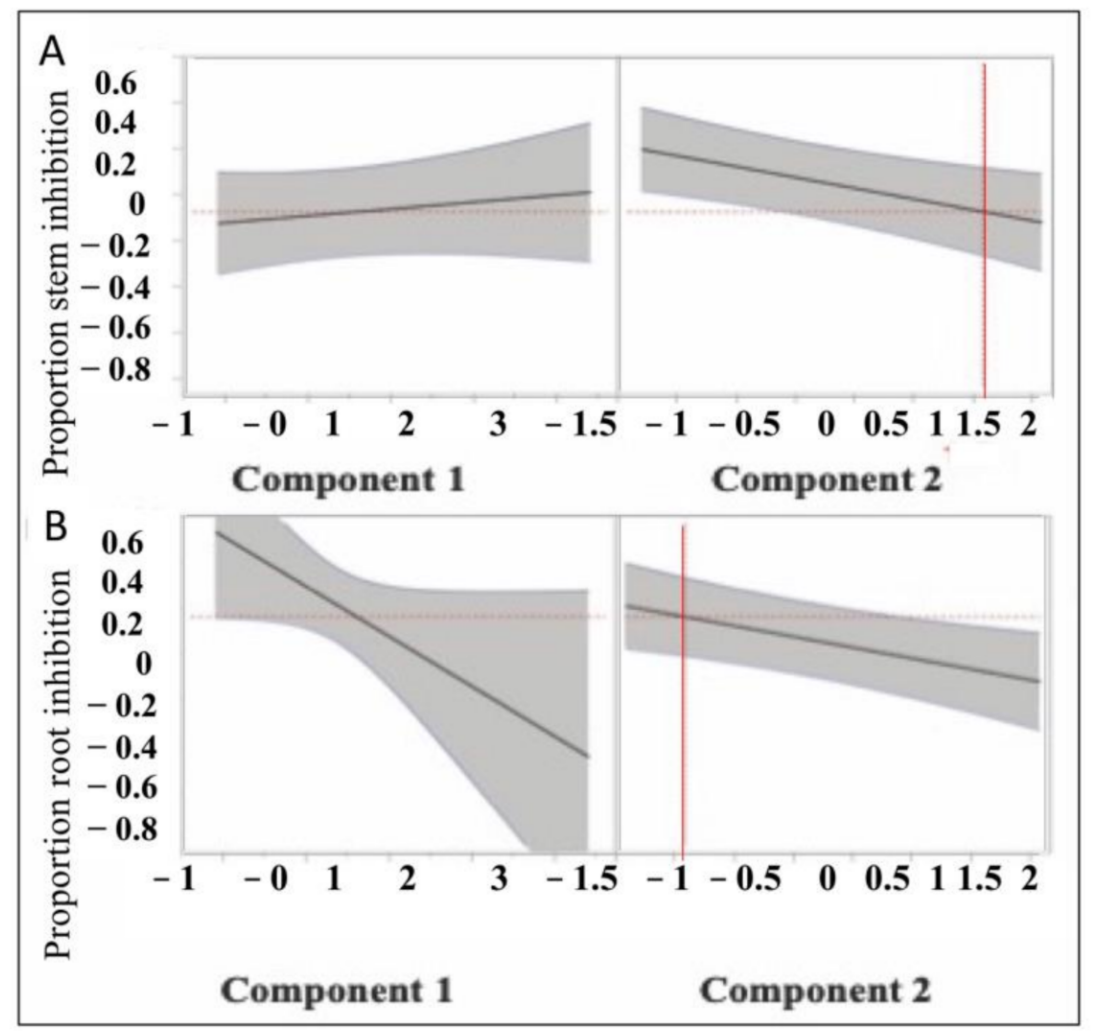

Figure 9. Prediction profiles for the effects of metal factor 1 and metal factor 2 on root inhibition. (A) Profile when metal component 2 is set to 1.5, and (B) profile when metal component 2 is set to -1.0 (high $\mathrm{Hg}$ and low $\mathrm{Pb}$ ). 
The results from this study demonstrate that interactions among complex mixtures of nutrients and metals in wetland ecosystems can produce relationships with bioindicators that run counter to the predictions made by considering individual pollutants independently [91]. For example, with the increase in $\mathrm{Pb}$, a decrease in root inhibition was observed in the factor analysis (Figure 4). However, a negative relationship in the regression analysis was observed between the plant bioindicators and $\mathrm{Pb}$ concentration (Table 2). For bacterial diversity, the detected $\mathrm{Hg}$, even at low concentrations, showed decreasing Shannon and Simpson diversity indices in the factor analysis (Figures 7 and 8), but a positive relationship was found in the regression analysis between bacterial bioindicators (Shannon and Simpson diversity indices) and $\mathrm{Hg}$ concentration (Table 3). The factor analysis showed a combined effect of the pollutants, whereas the regression analysis showed individual effects. All these conflicting trends open up a wide scope for further investigations. The effect of ecotoxicological and bacterial bioindicators needs to be thoroughly investigated in further studies with respect to the response to the pollutants (nutrients and metals) to establish a specific usage method. A controlled study with microcosms of these wetland sites, where the effects of pollutants (nutrients and metals) can be tested repeatedly on the bacterial and ecotoxicological bioindicators, can be very useful $[66,92]$. It also needs to be reiterated that these constructed wetlands are not very old [5-7]. Hence, these bioindicators can be applied and compared with the results found in natural wetlands. Although these comparisons were not under the scope of the present study, they may shed light on the contradictions found.

This study showed how disparate bioindicators (ecotoxicological and bacterial), which are quick, responsive, and well-established in the literature, can provide a clearer picture of ecological risk in constructed wetlands. The bacterial bioindicators showed us the immediate effect of a pollutant (for example, reduction in bacterial diversity with respect to $\mathrm{Hg}$ ), whereas plant bioindicators can show an impact after the pollutants have entered higher trophic levels. Therefore, these bioindicators are capable of predicting a wide range of impacts from pollutants and provide correlations and response patterns in relation to pollution-related stressors (such as nutrients and metals) entering the wetlands from the surrounding watershed. There are some contradictions in the results that can be investigated in future studies before these sets of bioindicators are clearly established as tools for measuring ecological integrity in freshwater constructed wetlands.

\section{Conclusions}

The ecotoxicological and bacterial taxonomical diversity bioindicators under investigation in this study demonstrated a clear correlation and specific predictive trends when analyzed with measured watershed pollutants, such as nutrients and metals detected in the wetland sediments and water. Hence, these bioindicators can serve as predictive bioindicators for ecological risk assessment of freshwater wetlands.

Author Contributions: T.J.E. assisted in the study conceptualization, design, data analysis, and funding of the project. The majority of the laboratory work was conducted in T.J.E.'s lab. C.F.W. contributed to the conceptualization and mentorship of the project and editing the manuscript. The microbial work was performed in C.F.W.'s laboratory. S.A.M. assisted in the field work, and with writing and editing the manuscript. S.G.R. did the conceptualization and field work of the project with the help of T.J.E., C.F.W. and S.A.M. S.G.R. also planned and conducted all the lab work, did the data collection, curation and analysis, did the original draft preparation, and the writing, reviewing and editing of the manuscript of the project. All authors have read and agreed to the published version of the manuscript.

Funding: Funding for this work was provided by The Village of Mount Pleasant (Racine, WI, USA) and the Wm. Collin Kohler's Foundation Sustainable Peacebuilding Fund at UW-Milwaukee.

Institutional Review Board Statement: Not applicable.

Informed Consent Statement: Not applicable. 
Data Availability Statement: Data about the landuse patterns of the wetland sites (1-6) can be referred from https: / / www.sewrpc.org/SEWRPC.htm (accessed on 14 March 2015). The Bioinformatics software used for microbial data analysis can be referred from https://mothur.org/ (accessed on 14 March 2015).

Acknowledgments: We want to thank The Village of Mount Pleasant (Racine, WI, USA) and Wm. Collin Kohler's foundation for supporting this study.

Conflicts of Interest: The authors declare no conflict of interest.

\section{Appendix A}

Table A1. The relative abundance of some of the most abundant bacterial orders and genera identified in the collected wetland sediments during summer 2015, fall 2016, and summer 2017, identified by 16 S rRNA gene sequencing in wetland sites $1,2,4,5$, and 6 .

\begin{tabular}{|c|c|c|c|c|c|c|c|}
\hline Genera & Summer 15 & Fall 16 & Summer 17 & Order & Summer 15 & Fall 16 & Summer 17 \\
\hline Bacillus & 60.30 & 3.85 & 0.04 & Rhodospirillales & 3.24 & 1.68 & 4.56 \\
\hline Clostridium & 16.86 & 18.62 & 18.11 & Vibrionales & 9.60 & 0.00 & 0.00 \\
\hline Pseudomonas & 3.19 & 26.24 & 41.67 & Saprospirales & 6.64 & 3.22 & 12.03 \\
\hline Streptococcus & 2.20 & 0.71 & 2.00 & Bacillales & 59.49 & 7.33 & 3.39 \\
\hline Bdellovibrio & 4.70 & 0.00 & 25.90 & Bacteroidales & 5.74 & 2.46 & 15.80 \\
\hline Flavobacterium & 5.97 & 5.29 & 11.84 & Caldilineales & 3.36 & 1.84 & 3.10 \\
\hline Treponema & 3.60 & 2.17 & 12.22 & Clostridiales & 15.24 & 10.91 & 17.97 \\
\hline Thiobacillus & 5.54 & 8.52 & 16.04 & Myxococcales & 8.37 & 2.97 & 9.84 \\
\hline Paenibacillus & 2.81 & 0.00 & 0.00 & Pirellulales & 5.01 & 2.60 & 6.20 \\
\hline Gemmata & 2.86 & 0.00 & 0.00 & Actinomycetales & 20.39 & 5.90 & 12.09 \\
\hline Vibrio & 13.04 & 0.00 & 0.00 & Burkholderiales & 14.25 & 101.86 & 52.31 \\
\hline Pelomonas & 0.00 & 47.62 & 5.31 & Rhizobiales & 9.86 & 6.92 & 17.27 \\
\hline Herbaspirillum & 0.00 & 20.66 & 2.39 & Xanthomonadales & 6.81 & 7.19 & 10.53 \\
\hline Geobacter & 1.89 & 5.61 & 3.50 & Desulfuromonadales & 0.79 & 8.74 & 1.41 \\
\hline Gaiella & 1.41 & 4.35 & 0.00 & Gaiellales & 2.64 & 11.71 & 2.84 \\
\hline Sphingomonas & 0.00 & 11.33 & 10.13 & Rhodocyclales & 2.67 & 4.38 & 9.12 \\
\hline Ralstonia & 0.00 & 3.49 & 0.34 & Pseudomonadales & 3.69 & 9.62 & 18.59 \\
\hline SJA-88 & 0.00 & 2.01 & 11.42 & Rhizobiales & 9.86 & 6.92 & 17.27 \\
\hline Rhodobacter & 0.00 & 0.00 & 5.78 & Sphingomonadales & 2.43 & 6.29 & 15.34 \\
\hline Hyphomicrobium & 1.76 & 0.00 & 4.81 & Bdellovibrionales & 1.69 & 0.68 & 10.97 \\
\hline Crenothrix & 2.90 & 2.17 & 10.26 & Fusobacteriales & 0.62 & 0.00 & 6.12 \\
\hline \multirow[t]{5}{*}{ Methylotenera } & 1.50 & 4.74 & 10.29 & Rhodocyclales & 2.67 & 4.38 & 9.12 \\
\hline & & & & Flavobacteriales & 3.79 & 2.81 & 6.92 \\
\hline & & & & Rhodobacterales & 3.36 & 1.58 & 6.48 \\
\hline & & & & Pirellulales & 5.01 & 2.60 & 6.20 \\
\hline & & & & Myxococcales & 8.37 & 2.97 & 9.84 \\
\hline
\end{tabular}




\section{Appendix B}

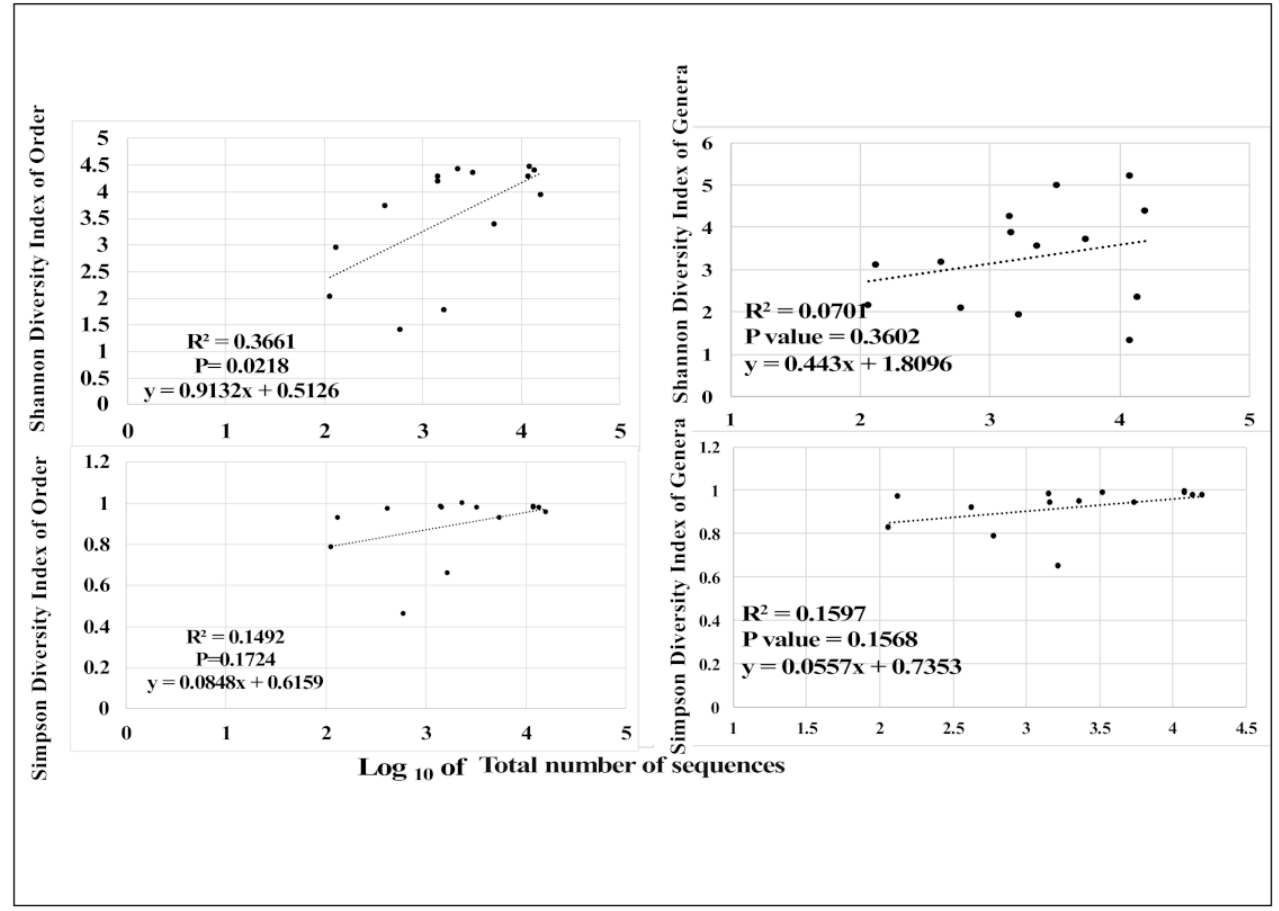

Figure A1. Scatterplot and line of fit for the Shannon and Simpson diversity indices of order and genera identified by $16 \mathrm{~S}$ rRNA gene sequencing in samples from wetland sites 1-6. Sequence numbers are shown as $\log _{10}$ values.

\section{References}

1. Rathbun, J.E.; Huellmantel, L.L.; Tracy, M.; Smith, V.E.; Ahlgren, K. Rapid Sediment Assessment: Indicator Analysis and Screening Analysis Approaches. J. Great Lakes Res. 1996, 22, 523-533. [CrossRef]

2. Steinman, A.D.; Scott, J.; Green, L.; Partridge, C.; Oudsema, M.; Hassett, M.; Kindervater, E.; Rediske, R.R. Persistent organic pollutants, metals, and the bacterial community composition associated with microplastics in Muskego Lake (MI). J. Great Lakes Res. 2020, 46, 1444-1458. [CrossRef]

3. Weigelhofer, G.; Hein, T.E.; Bondar-Kunze, E. Phosphorus and Nitrogen Dynamics in Riverine Systems: Human Impacts and Management Options. In Riverine Ecosystem Management: Science for Governing towards a Sustainable Future; Schmutz, S., Sendzimir, J., Eds.; Springer International Publishing: Cham, Germany, 2018; pp. 187-202.

4. Ali, H.; Khan, E.; Ilahi., I. Environmental Chemistry and Ecotoxicology of Hazardous Heavy Metals: Environmental Persistence, Toxicity, and Bioaccumulation. J. Chem. 2019, 6730305. [CrossRef]

5. Crispell-Synder, I. Executive Summary of WDNR Facilitation Presentation for Pike River Improvements by Mount Pleasant Storm Water Drainage District No 1. Pike River Improvement Project; 1997. Available online: http://www.mtpleasantwi.gov/23 25/Pike-River-Improvements-Project (accessed on 19 March 2016).

6. Ehlinger, T.; DeThorne, L.; Berner, B. Monitoring of Stream Habitat and Aquatic Biotic Integrity_Pike River North and South Branches, Racine and Kenosha Counties, Wisconsin; University of Wisconsin Milwaukee: Milwaukee, WI, USA, 2009.

7. Ehlinger, T.; DeThorne, L. Monitoring of Stream Habitat and Aquatic Biotic Integrity-Pike River North and South Branches, Racine and Kenosha Counties, Wisconsin, Interim Report; University of Wisconsin Milwaukee: Milwaukee, WI, USA, 2004.

8. Tixier, G.; Lafont, M.; Grapentine, L.; Rochfort, Q.; Marsalek, J. Ecological risk assessment of urban stormwater ponds: Literature review and proposal of a new conceptual approach providing ecological quality goals and the associated bioassessment tools. Ecol. Indic. 2011, 11, 1497-1506. [CrossRef]

9. Marsalek, J.; Rochfort, Q.; Grapentine, L. Aquatic habitat issues in urban stormwater management: Challenges and potential solutions. Ecohydrol. Hydrobiol. 2005, 5, 269.

10. Moreno-Mateos, D.; Power, M.E.; Comín, F.A.; Yockteng, R. Structural and functional loss in restored wetland ecosystems. PLoS Biol. 2012, 10, e1001247. [CrossRef]

11. Bodelier, P.; Dedysh, S. Microbiology of wetlands. Front. Microbiol. 2013, 4, 79. [CrossRef]

12. Knox, A.; Nelson, E.; Halverson, N.; Gladden, J. Long-Term Performance of a Constructed Wetland for Metal Removal. Soil Sediment Contam. 2010, 19, 667-685. [CrossRef] 
13. Banach, A.M.; Kuźniar, A.; Grządziel, J.; Wolińska, A. Azolla filiculoides L. as a source of metal-tolerant microorganisms. PLoS ONE 2020, 15, e0232699. [CrossRef] [PubMed]

14. Groffman, P.; Hanson, G.; Kiviat, E.; Stevens, G. Variation in Microbial Biomass and Activity in Four Different Wetland Types. Soil Sci. Soc. Am. J. 1996, 60, 622. [CrossRef]

15. Xie, Y.; Fan, J.; Zhu, W.; Amombo, E.; Lou, Y.; Chen, L.; Fu, J. Effect of heavy metals pollution on soil microbial diversity and Bermudagrass genetic variation. Front. Plant Sci. 2016, 7, 755. [CrossRef] [PubMed]

16. Sobolev, D.; Begonia, M. Effects of heavy metal contamination upon soil microbes: Lead-induced changes in general and Denitrifying microbial communities as evidenced by molecular markers. Int. J. Environ. Res. Public Health 2008, 5, 450-456. [CrossRef] [PubMed]

17. Zhao, J.; Zhao, X.; Chao, L.; Zhang, W.; You, T.; Zhang, J. Diversity change of microbial communities responding to zinc and arsenic pollution in a river of northeastern china. J. Zhejiang Univ. Sci. B 2014, 15, 670-680. [CrossRef]

18. Müller, A.K.; Westergaard, K.; Christensen, S.; Sørensen, S.J. The effect of long-term mercury pollution on the soil microbial community. FEMS Microbiol. Ecol. 2001, 36, 11-19. [CrossRef]

19. Frossard, A.; Donhauser, J.; Mestrot, A.; Gygax, S.; Bååth, E.; Frey, B. Long- and short-term effects of mercury pollution on the soil microbiome. Soil Biol. Biochem. 2018, 120, 191-199. [CrossRef]

20. An, F.; Diao, Z.; Lv, J. Microbial diversity and community structure in agricultural soils suffering from 4 years of Pb contamination. Can. J. Microbiol. 2018, 64, 305-316. [CrossRef]

21. Gummersheimer, B.S.; Giblin, T. Identification of Lead Resistant Bacteria from a Heavily Contaminated Site. Beta Beta Beta Biol. Soc. Stable JSTOR 2003, 74, 48-54.

22. Aylagas, E.; Borja, Á.; Tangherlini, M.; Dell'Anno, A.; Corinaldesi, C.; Michell, C.T. A bacterial community-based index to assess the ecological status of estuarine and coastal environments. Mar. Pollut. Bull. 2017, 114, 679-688. [CrossRef]

23. Olsen, G.J.; Lane, D.J.; Giovannoni, S.J.; Pace, N.R.; Stahl, D.A. Microbial ecology and evolution: A ribosomal RNA approach. Annu. Rev. Microbiol. 1986, 40, 337-365. [CrossRef]

24. Janda, J.; Abbott, S. 16S rRNA Gene Sequencing for Bacterial Identification in the Diagnostic Laboratory: Pluses, Perils, and Pitfalls. J. Clin. Microbiol. 2007, 45, 2761-2764. [CrossRef]

25. Pace, N.R.; Stahl, D.A.; Lane, D.J.; Olsen, G.J. The Analysis of Natural Microbial Populations by Ribosomal RNA Sequences. In Advances in Microbial Ecology; Marshall, K.C., Ed.; Springer: Boston, MA, USA, 1986; Volume 9, pp. 1-55.

26. Winters, A.D.; Marsh, T.L.; Brenden, T.O.; Faisal, M. Analysis of bacterial communities associated with the benthic amphipod Diporeia in the Laurentian great lakes basin. Can. J. Microbiol. 2014, 61, 72-81. [CrossRef]

27. Bouzat, J.L.; Hoostal, M.J.; Looft, T. Spatial patterns of bacterial community composition within Lake Erie sediments. J. Great Lakes Res. 2013, 39, 344-351. [CrossRef]

28. Shange, R.; Haugabrooks, E.; Ankumah, R.; Ibekwe, A.; Smith, R.; Dowd, S. Assessing the Diversity and Composition of Bacterial Communities across a Wetland. Transition, Upland Gradient in Macon County Alabama. Diversity 2013, 5, 461-478. [CrossRef]

29. Bucci, J.P.; Szempruch, A.J.; Caldwell, J.M.; Ellis, J.C.; Levine, J.F. Seasonal changes in microbial community structure in freshwater stream sediment in a North Carolina river basin. Diversity 2014, 6, 18-32. [CrossRef]

30. Parmar, T.K.; Rawtani, D.; Agrawal, Y.K. Bioindicators: The natural indicator of environmental pollution. Front. Life Sci. 2016, 9, 110-118. [CrossRef]

31. Microbiotest Inc. Standard Operating Procedure. Phytotoxkit. Seed Germination and Early Growth Microbiotest with Higher Plants. 2019. Available online: https:/ /www.microbiotests.com/wp-content/uploads/2019/05/Phytotoxicity-test_Phytotoxkitsolid-samples_Standard-Operating-Procedure.pdf (accessed on 10 January 2019).

32. Czerniawska-Kusza, I.; Ciesielczuk, T.; Kusza, G.; Cichon, A. Comparison of the Phytotoxkit microbiotest and chemical variables for toxicity evaluation of sediments. Environ. Toxicol. 2006, 21, 367-372. [CrossRef]

33. Czerniawska-Kusza, I.; Kusza, G. The potential of the Phytotoxkit microbiotest for hazard evaluation of sediments in eutrophic freshwater ecosystems. Environ. Monit. Assess. 2011, 179, 113-121. [CrossRef] [PubMed]

34. Persoone, G.; Vangheluwe, M. Toxicity determination of the sediments of the river Seine in France by application of a battery of microbiotests. In New Microbiotests for Routine Toxicity Screening and Biomonitoring; Kluwer Academic: New York, NY, USA, 2000; pp. $427-436$.

35. Ghosh Roy, S.; Ehlinger, T.J.; Jablonski, M.R. Effect of metals on growth inhibitions of Sinapis, Sorghum and Lepidium in textile dye waste contaminated soil, India. JEPEG 2019, 20, 608-619.

36. Murray, K.S.; Rogers, D.T.; Kaufman, M.M. Heavy metals in an urban watershed in southeastern Michigan. J. Environ. Qual. 2004, 33, 163-172. [CrossRef]

37. Hobbie, S.E.; Finlay, J.C.; Janke, B.D.; Nidzgorski, D.A.; Millet, D.B.; Baker, L.A. Contrasting nitrogen and phosphorus budgets in urban watersheds and implications for managing urban water pollution. Proc. Natl. Acad. Sci. USA 2017, 114, 4177-4182. [CrossRef]

38. SEWRPC, Racine County Mapbook, 2010. Available online: https://www.sewrpc.org/SEWRPC.htm (accessed on 14 March 2015).

39. Ghosh Roy, S.; Ehlinger, T.J. Relationships between land use, predicted pollution loadings and ecotoxicological assays in constructed wetlands. Rom. J. Ecol. Environ. Chem. 2020, 2, 118-129. 
40. Storer, D.A. A simple high sample volume ashing procedure for determination of soil organic matter. Commun. Soil Sci. Plant Anal. 1984, 15, 759-772. [CrossRef]

41. YSI. YSI a Xylem Brand. 2020. Available online: https://www.ysi.com (accessed on 19 March 2016).

42. Hach, Nitrate, Cadmium Reduction Method, 8039. USA. 2019. Available online: https://www.hach.com (accessed on 19 March 2016).

43. Hach, Phosphorus, Reactive (Orthophosphate), 8048. USA. 2019. Available online: https://www.hach.com (accessed on 19 March 2016).

44. Baranowski, R.; Rybak, A.; Baranowska, I. Speciation Analysis of Elements in Soil Samples by XRF. Pol. J. Environ. Stud. 2002, 11, 473-482.

45. Kenna, T.C.; Nitsche, F.O.; Herron, M.M.; Mailloux, B.J.; Peteet, D.; Sritrairat, S.; Sands, E.; Baumgarten, J. Evaluation and calibration of a Field Portable X-Ray Fluorescence spectrometer for quantitative analysis of siliciclastic soils and sediments. J. Anal. At. Spectrom. 2011, 26, 395-405. [CrossRef]

46. Díaz Rizo, O.; Gelen Rudnikas, A.; Lavin Pérez, R.D.; Arencibia Caraballo, G.; Alessandro Rodríguez, K.D. XRF analysis of sediments from Nuevitas Bay (Cuba): Assessment of current heavy metal contamination. Nucleus 2014, 55, 11-14.

47. Bruker. 2017. Available online: https://www.bruker.com/events/users-meetings/microct/2017.html (accessed on 9 February 2018).

48. EPA. Field Portable X-ray Fluorescence Spectrometry for the Determination of Elemental Concentrations in Soil and Sediment. 2007. Available online: https:/ / www.epa.gov/sites/production/files/2015-12/documents/6200.pdf (accessed on 24 April 2018).

49. DiScenza, D.J.; Keimowitz, A.R.; Fitzgerald, N. Calibration and Evaluation of an X-ray Fluorescence Method for the Determination of Lead and Arsenic in Soils. J. Environ. Anal. Chem. 2014, 1, 1-3. [CrossRef]

50. NIST. National Institute of Standards and Technology. 2013. Available online: https:/ /www.nist.gov (accessed on 19 March 2018).

51. Zieba-Palus, J.; Kunicki, M. Application of the micro-fTIR spectroscopy, Raman spectroscopy and XRF method examination of inks. Forensic Sci. Int. 2006, 158, 164-172. [CrossRef] [PubMed]

52. MP Biomedicals, Fast DNA TM Spin Kit. 2017. Available online: https:/ / www.mpbio.com (accessed on 16 March 2016).

53. Li, J.; Li, B.; Zhou, Y.; Xu, J.; Zhao, J. A rapid DNA extraction method for PCR amplification from wetland soils. Lett. Appl. Microbiol. 2011, 52, 626-633. [CrossRef] [PubMed]

54. Burbach, K.; Seifert, J.; Pieper, D.H.; Camarinha-Silva, A. Evaluation of DNA extraction kits and phylogenetic diversity of the porcine gastrointestinal tract based on Illumina sequencing of two hypervariable regions. Microbiologyopen 2016, 5, 70-82. [CrossRef] [PubMed]

55. Jiang, X.T.; Peng, X.; Deng, G.H.; Sheng, H.F.; Wang, Y.; Zhou, H.W.; Tam, N.F.Y. Illumina Sequencing of 16S rRNA Tag Revealed Spatial Variations of Bacterial Communities in a Mangrove Wetland. Environ. Microbiol. 2013, 66, 96-104. [CrossRef] [PubMed]

56. Schloss, P.D. Introducing mothur: Open-source, platform-independent, community-supported software for describing and comparing microbial communities. Appl. Environ. Microbiol. 2009, 75, 7537-7541. [CrossRef] [PubMed]

57. Sokal, R.; Rohlf, J. Biometry, 2nd ed.; W.H. Freeman and Company: San Fransisco, CA, USA, 1981.

58. SAS. JMP ${ }^{\circledR}$, Version $<14>$; SAS Institute Inc.: Cary, NC, USA, 2019; Available online: https://www.jmp.com/en_us/home.html (accessed on 10 January 2015).

59. Manikandan, R.; Sahi, S.V.; Venkatachalam, P. Impact assessment of mercury accumulation and biochemical and molecular response of Mentha arvensis: A potential hyperaccumulator plant. Sci. World J. 2015, 2015, 715217. [CrossRef] [PubMed]

60. Heidenreich, B.; Mayer, K.; Sandermann, H.J.; Ernst, D. Mercury-induced genes in Arabidopsis thaliana: Identification of induced genes upon long-term mercuric ion exposure. Plant Cell Environ. 2001, 24, 1227-1234. [CrossRef]

61. Baker, A.J.M.; McGrath, S.P.; Reeves, R.D.; Smith, J.A.C. Metal hyperaccumulator plants: A review of the ecology and physiology of biochemical resource for phytoremediation of metal-polluted soils. In Phytoremediation Contaminated Soil Water; CRC Press: Boca Raton, FL, USA, 1999; pp. 85-107.

62. Liu, C.W.; Sung, Y.; Chen, B.C.; Lai, H.Y. Effects of nitrogen fertilizers on the growth and nitrate content of lettuce (Lactuca sativa L.). Int. J. Environ. Res. Public Health 2014, 11, 4427-4440. [CrossRef]

63. Pang, J.; Ryan, M.H.; Tibbett, M.; Cawthray, G.R.; Siddique, K.H.M.; Bolland, M.D.A.; Denton, M.D.; Lambers, H. Variation in morphological and physiological parameters in herbaceous perennial legumes in response to phosphorus supply. Plant Soil 2010, 331, 241-255. [CrossRef]

64. López-Luna, J.; González-Chávez, M.; Esparza-García, F.; Rodríguez-Vázquez, R. Toxicity assessment of soil amended with tannery sludge, trivalent chromium and hexavalent chromium, using wheat, oat and sorghum plants. J. Hazard. Mater. 2009, 163, 829-834. [CrossRef]

65. Gerik, T.; Bean, B.; Vanderlip, R. Sorghum Growth and Development; Texas A\&M University System: College Station, TX, USA, 2010. Available online: http:/ / glasscock.agrilife.org/files/2015/05/Sorghum-Growth-and-Development.pdf (accessed on 7 July 2016).

66. Zhang, D.; Luo, J.; Lee, Z.; Maspolim, Y.; Gersberg, R.; Liu, Y. Characterization of bacterial communities in wetland mesocosms receiving pharmaceutical-enriched wastewater. Ecol. Eng. 2016, 90, 215-224. [CrossRef]

67. Calheiros, C.S.C.; Teixeira, A.; Pires, C.; Franco, A.R.; Duque, A.F.; Crispim, L.F.C.; Moura, S.C.; Castro, P.M.L. Bacterial community dynamics in horizontal flow constructed wetlands with different plants for high salinity industrial wastewater polishing. Water Res. 2010, 44, 5032-5038. [CrossRef] 
68. Ligi, T.; Oopkaup, K.; Truu, M.; Preem, J.K.; Nõlvak, H.; Mitsch, W.J.; Truu, J. Characterization of bacterial communities in soil and sediment of a created riverine wetland complex using high-throughput 16SrRNA amplicon sequencing. Ecol. Eng. 2014, 72, 56-66. [CrossRef]

69. Zhang, M.J.; Huang, F.K.; Wang, G.Y.; Liu, X.Y.; Wen, J.K.; Zhang, X.S.; Huang, Y.S.; Xia, Y. Geographic distribution of cadmium and its interaction with the microbial community in the Longjiang River: Risk evaluation after a shocking pollution accident. Sci. Rep. 2017, 7, 227. [CrossRef]

70. Wang, Y.; Sheng, H.F.; He, Y.; Wu, J.Y.; Jiang, Y.X.; Tam, N.F.Y.; Zhou, H.W. Comparison of the levels of bacterial diversity in freshwater, intertidal wetland, and marine sediments by using millions of illumina tags. Appl. Environ. Microbiol. 2012, 78, 8264-8271. [CrossRef] [PubMed]

71. Ding, X.; Peng, X.J.; Jin, B.S.; Xiao, M.; Chen, J.K.; Li, B.; Fang, C.M.; Nie, M. Spatial distribution of bacterial communities driven by multiple environmental factors in a beach wetland of the largest freshwater lake in China. Front. Microbiol. 2015, 6, 129. [CrossRef] [PubMed]

72. Stoeva, M.K.; Aris-Brosou, S.; Chételat, J.; Hintelmann, H.; Pelletier, P.; Poulain, A.J. Microbial community structure in lake and Wetland sediments from a high arctic polar desert revealed by targeted Transcriptomics. PLoS ONE 2014, e89531. [CrossRef]

73. Hughes, J.; Bohannan, B. Application of ecological diversity statistics in microbial ecology. In Molecular Microbial Ecology Manual, 2nd ed.; Springer: Dordrecht, The Netherlands, 2004; pp. 1321-1344.

74. Begon, M.; Harper, J.L.; Townsend, C.R.; Begon, M. Ecology: Individuals, Populations, and Communities, 3rd ed.; Blackwell Science: Oxford, UK, 1996.

75. Karr, J.R.; Chu, E.W. Restoring Life in Running Waters; Island Press: Washington, DC, USA; Covelo, CA, USA, 1999.

76. Magurran, A. Measuring Biological Diversity; Blackwell Publishing: Malden, MA, USA, 2004.

77. Faoro, H.; Alves, A.C.; Souza, E.M.; Rigo, L.U.; Cruz, L.M.; Al-Janabi, S.M.; Monteiro, R.A.; Baura, V.A.; Pedrosa, F.O. Influence of soil characteristics on the diversity of bacteria in the southern brazilian atlantic forest. Appl. Environ. Microbiol. 2010, 76, 4744-4749. [CrossRef] [PubMed]

78. Yu, J.; Lv, X.; Ma, B.; Qu, F.; Ning, K.; Wu, H. A meta-analysis of the bacterial and archaeal diversity observed in wetland soils. Salt Marshes Ecosyst. Veg. Restor. Strateg. 2014, 2014, 13-32.

79. USEPA. The Sources and Solutions: Agriculture. 2016. Available online: https://www.epa.gov/nutrientpollution/sources-andsolutions-agriculture (accessed on 7 July 2016).

80. Ward, M.H. Too much of a good thing? Nitrate from nitrogen fertilizers and cancer. Rev. Environ. Health 2009, $24,357-363$. [CrossRef] [PubMed]

81. Trajanovska, S.; Britz, M.L.; Bhave, M. Detection of heavy metal ion resistance genes in Gram-positive and Gram-negative bacteria isolated from a lead contaminated site. Biodegradation 1997, 8, 113-124. [CrossRef]

82. Gadd, G.M. Heavy Metal Pollutants: Environments and Biotechnological Aspects, Encycloped; Academic Press Inc.: San Diego, CA, USA, 1992.

83. Chen, B.; Liu, J.; Wang, Z.; Dong, L.; Fan, J.; Qu, J. Remediation of Pb-Resistant Bacteria to Pb Polluted Soil. J. Environ. Prot. 2011, 2, 30-141. [CrossRef]

84. Zhang, W.; Huang, Z.; He, L.; Sheng, X. Assessment of bacterial communities and characterization of lead-resistant bacteria in the rhizosphere soils of metal-tolerant Chenopodium ambrosioides grown on lead-zinc mine tailings. Chemosphere 2012, 87, 1171-1178. [CrossRef] [PubMed]

85. Jarosławiecka, A.; Piotrowska-Seget, Z. Lead resistance in micro-organisms. Microbiology 2014, 160, 12-25. [CrossRef] [PubMed]

86. Jebara, S.H.; Abdelkerim, S.; Fatnassi, I.C.; Chiboub, M.; Saadani, O.; Jebara, M. Identification of effective Pb resistant bacteria isolated from Lens culinaris growing in lead contaminated soils. J. Basic Microbiol. 2015, 55, 346-353. [CrossRef]

87. Figueiredo, N.L.L.; Canário, J.; Duarte, A.; Serralheiro, M.L.; Carvalho, C. Isolation and characterization of mercury-resistant bacteria from sediments of tagus estuary (Portugal): Implications for environmental and human health risk assessment. J. Toxicol. Environ. Health Part A Curr. Issues 2014, 77, 155-168. [CrossRef]

88. Naguib, M.; Khairalla, A.; El-Gendy, A.; Elkhatib, W. Isolation and Characterization of mercury-resistant bacteria from wastewater sources in Egypt. Can. J. Microbiol. 2019, 65, 308-321. [CrossRef]

89. Irawati, W.; Patricia; Soraya, Y.; Hugo Baskoro, A. A Study on Mercury-Resistant Bacteria Isolated from a Gold Mine in Pongkor Village, Bogor, Indonesia. HAYATI J. Biosci. 2012, 19, 197-200. [CrossRef]

90. Kowalczyk, A.; Wilińska, M.; Chyc, M.; Bojko, M.; Latowski, D. Isolation, screening and identification of mercury resistant bacteria from mercury contaminated soil. E3S Web Conf. 2016, 10, 1-6. [CrossRef]

91. Alia, N.; Sardar, K.; Said, M.; Salma, K.; Sadia, A.; Sadaf, S.; Toqeer, A.; Miklas, S. Toxicity and bioaccumulation of heavy metals in spinach (Spinacia oleracea) grown in a controlled environment. Int. J. Environ. Res. Public Health 2015, 12, 7400-7416. [CrossRef] [PubMed]

92. Messer, T.; Burchell, M.; Birgand, F.; Broome, S.; Chescheir, G. Nitrate removal potential of restored wetlands loaded with agricultural drainage water: A mesocosm scale experimental approach. Ecol. Eng. 2017, 106, 541-554. [CrossRef] 